\title{
Managing Water and Soils to Achieve Adaptation and Reduce Methane Emissions and Arsenic Contamination in Asian Rice Production
}

\author{
Dennis Wichelns \\ Tel.: +66-2-2514-4158 \\ Academic Editors: Ashantha Goonetilleke and Meththika Vithanage \\ Received: 22 January 2016; Accepted: 15 March 2016; Published: 9 April 2016
}

Stockholm Environment Institute, Asia Centre, Bangkok 10330, Thailand; dennis.wichelns@sei-international.org;

\begin{abstract}
Rice production is susceptible to damage from the changes in temperature and rainfall patterns, and in the frequency of major storm events that will accompany climate change. Deltaic areas, in which millions of farmers cultivate from one to three crops of rice per year, are susceptible also to the impacts of a rising sea level, submergence during major storm events, and saline intrusion into groundwater and surface water resources. In this paper, I review the current state of knowledge regarding the potential impacts of climate change on rice production and I describe adaptation measures that involve soil and water management. In many areas, farmers will need to modify crop choices, crop calendars, and soil and water management practices as they adapt to climate change. Adaptation measures at the local, regional, and international levels also will be helpful in moderating the potential impacts of climate change on aggregate rice production and on household food security in many countries. Some of the changes in soil and water management and other production practices that will be implemented in response to climate change also will reduce methane generation and release from rice fields. Some of the measures also will reduce the uptake of arsenic in rice plants, thus addressing an important public health issue in portions of South and Southeast Asia. Where feasible, replacing continuously flooded rice production with some form of aerobic rice production, will contribute to achieving adaptation objectives, while also reducing global warming potential and minimizing the risk of negative health impacts due to consumption of arsenic contaminated rice.
\end{abstract}

Keywords: aerobic rice; climate change; deltas; Mekong; mitigation; sustainable rice intensification

\section{Introduction}

Rice is the primary food crop for much of humanity, and rice production supports millions of livelihoods across Asia and in portions of Africa [1-5]. Rice production is moderately susceptible to damage from climate change. Rising temperatures and changes in the amount and timing of rainfall can impair plant growth and reduce crop yields [6-8]. The increasing atmospheric concentration of $\mathrm{CO}_{2}$ will enhance plant growth in some areas, with positive implications for crop yield, but the net impact of climate change will be negative in areas where the yield impairment due to rising temperatures or changing rainfall patterns is substantial. In regions as large and diverse as Asia and Africa, the impacts of climate change on rice production will vary with location and with differences in regional weather patterns and crop production settings [9].

Much of the rice production in South and Southeast Asia is found in the deltas formed by major rivers, such as the Mekong, Irrawaddy, Chao Phraya, and Ganges-Brahmaputra [10]. Rice is well adapted to these deltaic regions, many of which are characterized by monsoonal climates. Rice plants can tolerate extended periods in which the paddy soils are flooded or partly submerged, yet they are susceptible to damage from complete submergence caused by short-term or extended flooding [11-15]. 
The 2011 Southeast Asian flood caused water levels in Cambodia's Tonle Sap Lake to rise above normal for more than one month, destroying $12 \%$ of the area planted in rice in Battambang Province, with notable implications for livelihoods and food security in the region [16]. The frequency of such flooding is expected to increase with climate change [17-19]). In sum, rice production is susceptible to yield impairment due to several aspects of climate change, including changes in rainfall patterns, higher temperatures, and an increase in the frequency and severity of flooding events.

My goal in this paper is to describe adaptation measures that will assist in minimizing the potential damage to rice production from climate change, with a particular emphasis on soil and water management. I begin by reviewing the current state of knowledge regarding the direct and indirect impacts of climate change on rice production systems. The discussion includes many examples of climate change impacts and adaptation efforts already observed in several countries. I describe also the potential role of soil and water management in reducing the amount of methane generated and released from rice paddies each year and in reducing also the uptake of arsenic by rice in areas with high concentrations of arsenic in soils and groundwater. I conclude that improvements in soil and water management might be helpful in achieving several desirable objectives, including climate change adaptation and mitigation, and reducing a notable risk to public health in portions of South and Southeast Asia.

\section{Climate Change and Rice Production}

Climate change will impact rice production through a combination of direct and indirect effects. The direct effects include the implications of higher temperatures and changes in ambient carbon dioxide concentrations on the growth, development, and yield of rice plants [20,21]. Additionally in this category are the impacts of changes in rainfall patterns, humidity, solar radiation, and average wind speeds, which influence rice growth and grain yields [22-25]. The indirect effects include changes in crop water requirements and in water availability, particularly in areas where rice is irrigated. The impacts of sea level rise, coastal erosion, and saline intrusion into coastal aquifers also are among the indirect impacts of climate change on rice production [10,17].

\subsection{Direct Effects}

Climate change will impact rice production through increases in minimum and maximum temperatures, changes in the timing, duration, and intensity of rainfall events in basins where rice is cultivated, and the increasing concentration of $\mathrm{CO}_{2}$ in the atmosphere [26-28]). While higher ambient concentrations of $\mathrm{CO}_{2}$ can enhance crop yields, higher temperatures at critical stages of crop development can impair spikelet fertility and thus offset the potential increase in crop yields [29-33]. Higher $\mathrm{CO}_{2}$ concentrations can exacerbate the sterility impacts of higher temperatures by reducing the number of pollen grains deposited on the stigma [34]. The net effects of changes in temperature and $\mathrm{CO}_{2}$ concentrations likely will be negative in some locations and seasons, and positive in others, with variation across temperate and tropical climates [6,27].

In a controlled environment chamber experiment conducted at the University of Florida, Baker et al. [35] observed only small yield increases in response to $\mathrm{CO}_{2}$ enrichment, while higher temperatures notably reduced grain yields of the IR-30 rice cultivar. Cheng et al. [20], also using controlled environment chambers, showed that high night temperatures limit grain setting of the IR-72 cultivar, thus reducing the yield enhancing advantages of higher $\mathrm{CO}_{2}$ concentrations. Cai et al. [36] found that higher temperatures fully offset the potential gains in rice yields from higher levels of $\mathrm{CO}_{2}$, in a two-year, free-air $\mathrm{CO}_{2}$ enrichment (FACE) experiment in Jiangsu Province, China. Rice yields were reduced by $35 \%$ in 2013 and by $17 \%$ in 2014, at increased levels of both $\mathrm{CO}_{2}$ and temperature. The number of filled grains per $\mathrm{m}^{2}$ was significantly smaller in the presence of higher $\mathrm{CO}_{2}$ and higher temperature. The authors recommend research to increase the proportion of filled grains (or spikelet fertility) and grain number per $\mathrm{m}^{2}$, to prevent yield reductions due to climate change [36]. Wang et al. [37] report an average $4.7 \%$ reduction in rice yield, when both $\mathrm{CO}_{2}$ and temperature were 
increased, over the course of a four-year field experiment with a japonica hybrid cultivar, also in Jiangsu Province.

In areas where rainfall increases with climate change, rice yields might increase, although there might be offsetting impacts due to higher temperatures, particularly at night and during the booting, flowering, and grain-filling stages of production [10,26,38,39]. Higher humidity, in combination with higher temperatures, also can cause spikelet sterility and reduce grain quality [40,41]. Higher night temperatures had a larger, negative impact on rice yields and 1000-grain weights on two indica varieties in China, than did higher daytime temperatures [42].

Higher temperatures already impact rice production in tropical areas, resulting in smaller yields and lower grain quality [21]. The higher temperatures and increases in vapor pressure deficit that will accompany climate change can increase chalkiness, thus reducing head rice yields, particularly during the wet season, when humidity is high [43]. Both chalkiness and head rice yields are important quality characteristics that influence the prices farmers obtain for their rice [42,44]). Okada et al. [45] attribute the decline in rice quality observed in Western Japan since the 1990s to an increase in the occurrence of chalky grains. Dong et al. [46] observed significant yield reductions, smaller head rice yields, and increased chalkiness, due to higher night temperatures in a pot culture experiment in Jiangsu Province, China. Some of the impacts they observed varied across the two indica and japonica cultivars they tested, and with the position of rice grains on the panicle. Grain filling was significantly depressed on inferior kernels, while the filling rate for superior kernels was largely unchanged. The negative impacts of higher temperatures on grain yield and quality were more severe on the japonica variety than on the indica variety, suggesting that indica varieties might be more adaptable to higher temperatures [46].

Indeed, the impacts of higher night temperatures on rice yields might be smaller on the indica cultivars that are common in the tropics, than on the japonica varieties, which were developed in cooler regions (Dong et al. [46]). Some time ago, Weng and Chen [47] observed higher rates of photosynthesis, in the presence of higher temperatures, in indica varieties than in japonica varieties in an experimental setting. Peraudeau et al. [48] found that although night respiration increases with higher temperatures, the reduction in carbon assimilation and dry matter production is negligible with indica cultivars. Shah et al. [39] observed reductions in grain yield of $0 \%$ and $10 \%$ in 2009 , and $17 \%$ and $45 \%$ in 2010 , for indica and japonica varieties, respectively, in a field-scale experiment involving a $2{ }^{\circ} \mathrm{C}$ increase in night temperatures. The implications of higher night temperatures on carbon assimilation and grain yields are not yet fully understood. Welch et al. [49] propose additional research that investigates the impacts of minimum and maximum temperatures jointly, as the two temperatures can have offsetting impacts on rice yields.

In a simulation study of the potential impacts of climate change on rice production in the Mekong River basin, Mainuddin et al. [50,51] show that the yields of rainfed rice might increase in the upper portion of the basin (Laos and Thailand), while declining in the lower portion (Cambodia and Vietnam), due largely to changes in rainfall patterns and in ambient $\mathrm{CO}_{2}$ concentrations. The yields of irrigated rice in the Mekong River basin might be largely unaffected by climate change, if the projected increases in irrigation requirements can be satisfied [50]. The authors show also that some of the projected negative impacts on rainfed rice can be offset by implementing adaptation options, including changes in rice planting dates, increases in fertilizer applications, and provision of supplemental irrigation.

\subsection{Indirect Effects}

Several authors have examined the likely indirect effects of climate change on crop water requirements and water availability, largely with the aid of simulation models that project future conditions, in conjunction with prevailing climate change scenarios. Using such models for selected countries, Döll [52] projects that net irrigation requirements will increase notably in some countries and regions, while declining somewhat in others. The highest requirements will occur in hot, arid regions, such as northern Africa, while the lowest irrigation requirements will occur in cooler, humid 
regions, such as northern Europe and Southeast Asia. The projected changes in irrigation requirements are modified somewhat by changes in cropping patterns and crop calendars. For example, in some regions where the average annual temperature will increase and annual rainfall will decline with climate change, the net irrigation water requirement might also decline if farmers select alternative crops or shift their cultivation schedules to cooler, wetter portions of the year [52].

Elgaali et al. [53] also recommend changes in cropping patterns and crop calendars as adaptation responses to the increases in irrigation water requirements they project for the Arkansas River Basin in Southeastern Colorado. In that region, substantial increases in temperature and evapotranspiration will lead to higher irrigation water requirements in the spring season, while increases in humidity and reductions in solar radiation will reduce irrigation requirements in summer [53]. The net effect will be an increase in annual irrigation water requirements. Hence, in addition to adjusting their cropping patterns and crop calendars, farmers and water managers might invest also in new efforts to capture and store rainfall, and manage soil moisture effectively across seasons [53].

Estimates of changes in monthly weather conditions form the basis of the climate change projections prepared by Rehana and Mujumdar [54] for the Bhadra Reservoir command area in the Indian state of Karnataka. Irrigation water demands in rice production, which occurs from April through October, are expected to increase with climate change. The same is true for sugarcane production, although irrigation demands will increase in some months, while declining in others.

Shahid [55] examines monthly water use by rice in Bangladesh, where about $60 \%$ of the annual crop is produced during the Boro season, which occurs from January through May. This is the dry season in Bangladesh, such that all of the Boro rice is irrigated [56]. Climate change will bring higher temperatures and higher rates of evapotranspiration during the Boro season, thus increasing daily crop water requirements. However, the higher rates of evapotranspiration will modify the crop physiology and shorten the growing season, thus reducing the number of irrigation days [55]. Effective rainfall is projected to decline during January and February in northwestern Bangladesh, while increasing in March, April, and May. The projected net change in effective rainfall is positive [55]. The summary effect of these projected changes in evapotranspiration, effective rainfall, and irrigation days is largely neutral. The projected average irrigation water requirements for 2025, 2050, 2075, and 2100 are $1059 \mathrm{~mm}, 1036 \mathrm{~mm}, 1043 \mathrm{~mm}$, and $1044 \mathrm{~mm}$, respectively [55].

Mainuddin et al. [57] also project a small impact of climate change on the net irrigation requirement of Boro rice and other crops in Bangladesh. Using a daily water balance model, the authors estimate irrigation water requirements for all districts in the country, for average and dry climate conditions. The projected changes in rainfall, due to climate change, are quite small during the Boro season, such that changes in evapotranspiration largely determine the likely impact on net irrigation requirements. The authors project an average increase in the net irrigation requirement for Boro rice of $3 \%$, with a maximum increase of $5 \%$ in some districts, in their dry conditions scenario. The projected average increase for other crops is about $5 \%$, with a maximum increase of about $8 \%$ in some districts [57]. The authors suggest also that shifting the planting date of Boro season crops, either earlier or later, is not helpful in reducing the projected increase in net irrigation requirements. Thus, adjusting the crop calendar might not be effective in adapting to climate change during the dry season in Bangladesh [57].

Projections of the likely impacts of climate change on irrigation requirements are particularly timely in Bangladesh, given the heavy reliance on groundwater for irrigating rice and other crops in the Boro season. Much of the country's success in achieving self sufficiency in rice production is due to a substantial increase in groundwater pumping for irrigation [56,57]. Much of the increasing demand for groundwater in recent years is due to the expansion of irrigated area and the intensification of agriculture during the Boro season, rather than changes in rainfall or evapotranspiration [58,59]. Given that net irrigation requirements are projected to increase by an average of just 3\% to $5 \%$ for rice and other crops in the Boro season [57], it is possible that sustainable rates of groundwater pumping can be achieved in Bangladesh, although policy interventions might be required to reduce groundwater 
pumping in areas of notable overdraft, such as in the Barind and Madhupur Tracts and in Dhaka and nearby areas [58-60].

Unlike farmers in Bangladesh, rice farmers in Sri Lanka depend largely on rainfall and surface water supplies. Rice is produced on about $30 \%$ of the land area in Sri Lanka, and the activity directly supports about 800,000 farm families, most of whom cultivate less than 1 ha of land [61]. Farmers rely largely on inter-monsoonal and monsoon rains, thus placing them at substantial risk of crop failure in years when rainfall is limited or delayed [61]. Several authors have shown that rainfall in Sri Lanka declined during the latter half of the 20th century [62-64]. Domroes and Schaefer [65] suggest that the estimated average annual rainfall declined from $2005 \mathrm{~mm}$ during 1931 to 1960, to $1861 \mathrm{~mm}(7.2 \%)$ during 1961 to 1990 . Annual rainfall varies notably across the country. The wet zone in Southwestern Sri Lanka receives about $2000 \mathrm{~mm}$ of rainfall, while the dry zone in northern and eastern Sri Lanka receives only $800 \mathrm{~mm}$ to $1200 \mathrm{~mm}$ of rainfall per year [61]. Water storage and irrigation are particularly important activities in the dry zone.

The average annual rainfall in Sri Lanka is projected to increase by $14 \%$ in 2050 in the SRES A2 climate change scenario and by $5 \%$ in the SRES B2 scenario [61]. However, average annual rainfall during the dry season is projected to decline by $17 \%$ and $9 \%$ in the $\mathrm{A} 2$ and $\mathrm{B} 2$ scenarios, respectively. The average wet season temperature is projected to increase by $1.6^{\circ} \mathrm{C}$ and $1.3^{\circ} \mathrm{C}$ in the two scenarios, causing evapotranspiration to increase by $2 \%$ and $1 \%$, respectively [61]. The combination of higher temperatures and reduced rainfall will result in higher irrigation water requirements in the dry season. De Silva et al. [61] project increases in rice irrigation requirements of $23 \%$ and $13 \%$ in 2050 for the A2 and B2 scenarios. The largest proportional increase is projected for Batticaloa, in Eastern Sri Lanka (45\% and $13 \%$ in the A2 and B2 scenarios), while a small reduction in irrigation requirements is projected for Hambantota, in southern Sri Lanka ( $-2 \%$ and $-4 \%$ in the A2 and B2 scenarios). The projected reductions in average rainfall, in addition to projected shifts in the timing of the monsoon rains, and in combination with increases in evapotranspiration, will challenge rice producers, particularly in the dry zone. Earlier planting of rice and the use of shorter season varieties might be helpful in mitigating the potentially negative impacts [61]. In some areas of the country, it might become necessary to reduce the area planted in rice.

Elsewhere in Asia, climate change will increase average rainfall in South Korea by $25 \%$ to $53 \%$, yet effective rainfall will increase by only $2 \%$ to $8 \%$, resulting in a $1 \%$ to $8 \%$ reduction in rice irrigation requirements [66]. The ratio of available water resources to irrigation demands will increase accordingly, yet farmers and water agencies might consider investing in additional water storage, to mitigate water shortages in dry years. Wang et al. [67] project increases of $2 \%$ and $5 \%$ in rice irrigation requirements during 2046 to 2065 for the SR A1B and SR B1 climate change scenarios in southeastern China. The projected increases rise to more than 5\% and 15\% for 2081 to 2100 for the two scenarios, respectively. Ye et al. [68] project that rice water requirements will increase from an average of $700 \mathrm{~mm}$ during 1981 to 2000, to $1027 \mathrm{~mm}$ during 2011 to 2040, and to $1150 \mathrm{~mm}$ during 2071 to 2100 . The primary cause of the increase in rice irrigation requirements is the increase in average temperature that characterizes the A1B climate change scenario. Chiang and Liu [69], in a simulation of the SRES A2 and SRES B2 scenarios, show that climate change might cause water shortages as large as $27 \%, 29 \%$, and $31 \%$ of rice irrigation demand in southern Taiwan during the 2020s, 2050s, and 2080s, respectively, thus impacting rice output during the dry season. The impacts of the water shortages can be lessened, in part, by reducing planted area and minimizing conveyance losses in the irrigation system [69].

Kunimitsu et al. [70] examine the likely changes in rice productivity, due to climate change, across Japan. The authors determine that after the 2050s, climate change will increase rice yields in northern areas, such as Hokkaido and Tohoku, due largely to beneficial warming during the rice production season. By contrast, climate change will reduce rice yield and grain quality in other regions after the 2050s, while also increasing the variation in rice productivity. The authors suggest that much of the negative impact of climate change can be offset by transplanting rice earlier in the year, except in the 
southern region of Kyushu, provided that sufficient irrigation water will be available during April, as needed, to support an earlier transplanting schedule [70].

Naylor et al. [71] examine the potential impacts of climate change on rice production on the islands of Java and Bali, which generate about one-third and one-fifth of Indonesia's annual rice output, respectively. The authors suggest that the likelihood of a 30-day delay in the onset of the monsoon will increase with climate change, thus raising concern regarding food security and livelihoods in future. Rainfall likely will increase near the end of the crop year (April to June), while decreasing in the dry season (July to September). The authors recommend adaptation strategies that include greater investment in water storage, drought-tolerant crops, crop diversification, and early warning systems [71].

Indonesia already is susceptible to notable changes in annual rainfall associated with El Niño/Southern Oscillation (ENSO) events. Much of the rice production area in Indonesia is impacted by the warmer, drier conditions that prevail during El Niño years [72]. Impacts occur in both irrigated and non-irrigated settings, because the source of water for most of the irrigated rice production is a river, rather than a reservoir [73]. Only 800,000 ha of the 5.7 million ha of irrigated rice (14\%) are served by a storage reservoir. The negative impacts of El Niño events on rice production are evident also in the Philippines, where an El Niño-induced drought caused a $24 \%$ reduction in rice output in 1998, which resulted in localized food shortages [74]. Investments in water storage, where feasible, might be helpful in reducing the negative impacts of drought on rice production in Indonesia, the Phillipines, and elsewhere.

Climate change will impact rice production in many coastal areas, due to increases in storm events in the near term and a rising sea level, over time [10,17]. Many farmers in coastal areas of Bangladesh already struggle to sustain rice production, as several cyclones have moved saline water inland in recent years, causing salinlity levels in rice fields to rise sharply to levels that impair crop production [75]. Storm surges and salinity intrusion threaten both rice production and aquaculture in coastal areas of Bangladesh, where millions of residents depend on these activities for their livelihoods and household food security [76].

The Government of Indonesia expects that by 2050, sea level rise will cause the area planted in rice to decline by 182,556 ha on Java and Bali, 78,701 ha on Sulawesi, 25,372 ha on Kalimantan, 3170 ha on Sumatra, and 2123 ha on Lombok [77]. Farmers in Indonesia currently plant about 13 million ha in rice each year and they produce about 68 million tons of rice [78]. Nearly all of the rice is consumed domestically, as exports account for less than one percent of production [78]. Rice contributes substantially to the country's food security, accounting for $48 \%$ of the average daily consumption of $2600 \mathrm{kcals}$ per person, per day in Indonesia [78]. The country achieved rice self sufficiency in 2008 and the government plans to increase the area planted in rice and to intensify rice production methods, to maintain sufficient production in future $[79,80]$.

\subsection{Brown Planthoppers}

Climate change also might create conditions in which some pests of rice, such as the brown planthopper, will thrive, and will cause more damage than in the past. Severe infestations of brown planthopper have become more frequent in recent years in Indonesia and other tropical countries, due largely to the excessive use of nitrogen fertilizer on hybrid rice varieties and the misguided use of insecticides that destroy beneficial predators [81-85]). The loss of biodiversity in regions where rice production dominates the landscape also contributes to higher rates of infestation, as there is less supportive habitat for beneficial predators [86]. The brown planthopper is a phloem sucking insect that causes damage directly, while also transmitting viral diseases, such as grassy stunt and ragged stunt $[87,88]$.

Higher temperatures and elevated concentrations of $\mathrm{CO}_{2}$ likely will impact the development and life cycles of brown planthoppers and other insect pests of rice and many crops. Shi et al. [88] show that higher temperatures, alone, accelerate nymphal development, while reducing the weight of the 
$\mathrm{F} 1$ adults and their honeydew excretion. Elevated concentrations of $\mathrm{CO}_{2}$ increased the lifespan of brachypterous females, at ambient temperatures, but had no impact on female longevity at higher temperatures. Female fecundity was higher at higher temperatures and at elevated concentrations of $\mathrm{CO}_{2}$. Shi et al. [88] conclude that higher temperatures and higher levels of $\mathrm{CO}_{2}$, considered together, might lead to larger populations of brown planthoppers.

Interventions to reduce farm-level application of insecticides, while also modifying seeding rates and nitrogen applications, have been helpful in reducing the damage from brown planthoppers in several countries. Huan et al. $[89,90]$ and Heong et al. [91] report notable reduction in pesticide use among farmers in the Mekong Delta of Vietnam, in response to successful public education campaigns. Farmers adopting the recommended practices observed less damage from brown planthoppers and earned higher seasonal incomes, due largely to smaller expenditures on pesticides. Rice plants grown in hydroponic culture with high concentrations of silicon exhibited significant resistance to brown planthoppers, suggesting that silicon fertilizer might provide a useful, non-pesticide complement to chemical control efforts, particularly in the context of susceptible varieties [92]. Efforts to develop rice varieties that are resistant to brown planthoppers are underway, yet resistance likely should be regarded as just one component of an integrated management approach that includes wise use of fertilizer and insecticides [93].

\section{Adapting to Climate Change}

\subsection{Farm-Level Adaptation}

Farm-level adaptation efforts will vary with location and with the nature of the impacts observed. In some areas, farmers will respond to increasing variability in precipitation by investing in irrigation or enhancing efforts to capture and store rainfall. Investments in irrigation and rainwater capture are forms of adaptation that enable farmers to gain some control over the amount and timing of soil moisture available to plants, thus improving their resilience to the increased variation in rainfall due to climate change [94].

The most common form of farm-level adaptation to increasing water scarcity in the Rajshahi District of Bangladesh is greater use of groundwater for irrigation [95]. Other strategies include increasing the use of surface water and planting crops other than rice. Alauddin and Sarker [96] observed similar strategies in a survey involving 1800 farmers in several drought-prone and groundwater-depleted areas of Bangladesh. The four most preferred strategies for adapting to drought include planting shorter duration rice varieties, switching to non-rice crops in the dry season, applying more irrigation water in the dry season, and applying supplemental irrigation in the wet season [96]. Investments in irrigation in other countries also will be helpful in adapting to climate change, provided sufficient water resources are available [97].

Farmers in many areas will modify their crop choices and crop calendars, in response to changes in rainfall patterns and average temperatures. In some areas, climate-induced changes in the beginning and ending dates of the wet season will require that farmers modify rice planting and harvest dates, with potential implications for the number of crops produced each year, rice yields, and aggregate production [98]. Delays in planting might result in a shorter growing season and lower yields, while also possibly delaying the start of a subsequent season. Dharmarathna et al. [99] show that shifting the planting date for dry season rice forward by one month in the Kurunegala District of Sri Lanka will increase the average yield by $130 \mathrm{~kg}$ per ha, while delaying the planting date by one month will reduce the average yield by $170 \mathrm{~kg}$ per ha. Two-thirds of the rice farmers interviewed by Le Dang et al. [100] in the Mekong Delta of Vietnam report shifting their planting and harvest dates to accommodate changes in weather patterns. About $60 \%$ of the rice farmers modify their use of labor, while also changing the times at which they apply irrigation, fertilizer, and pesticides.

Farmers in Bangladesh also exhibit notable responsiveness to differences in seasonal rainfall and average temperatures. In lower rainfall areas, farmers prefer to cultivate irrigated rice in the dry 
season, while in higher rainfall areas, farmers prefer to grow rice during the wet season [101]. Farmers in low temperature zones prefer rainfed rice production in the wet season, while farmers in high temperature zones prefer irrigated rice production in the dry season. If climate change brings higher temperatures to Bangladesh, rainfed rice production might decline, while dry season rice production might increase [101].

Babel et al. [32] suggest that farmers in Thailand can increase rice yields by $23 \%$ to $34 \%$ by delaying the sowing date for rice by 20 to 30 days, to avoid high temperatures during the grain filling stage. In addition, advancing the date of nitrogen application by 10 days can improve crop yields. Changing the date of land preparation or modifying tillage practices, such as plowing and harrowing, had no significant impacts [32].

In a simulation study of the potential impacts of climate change in central Vietnam, Shrestha et al. [102] determine that the projected decrease in rice yields of $1 \%$ to $23 \%$ in the winter season can be offset by delaying the date of transplanting by one month and applying $100 \mathrm{~mm}$ of irrigation water in each of four events during the season. At present, winter rice production is largely rainfed in the region, although water for irrigation is available in perennial streams. Applying fertilizer in several doses, rather than a single dose, can increase rice yields by $1.8 \%$ to $5.1 \%$ [102].

Deb et al. [103] examine climate change scenarios and rice production in Ca Mau Province, in the Mekong Delta of Vietnam. They suggest that a delay in the date of transplanting will offset a portion of the expected decline in rice yields in the summer-autumn season, while an earlier date of transplanting will enhance rice yields in the autumn-winter season. In the summer-autumn season, a delay of 45 days is optimal, with regard to rice yields in 2025 and 2055. Delaying the date of transplanting by an additional 15 days in 2085 will further enhance rice yields in that year. These delays shift the weather-sensitive plant stages, such as flowering and reproduction, to periods with cooler temperatures and higher rainfall, thus increasing the likelihood of successful pollination and grain development. Advancing the date of transplanting in the autumn-winter season increases the likelihood of receiving sufficient rainfall during critical plant stages, while also minimizing the probability of chilling injury during anthesis and maturity [103].

Farmers in Cambodia also might offset some of the negative impacts of climate change by delaying rice planting. Chun et al. [94] suggest that a delay of 50 days beyond the baseline (for 1991 to 2000) planting date, in conjunction with an increase in nitrogen fertilizer application to $100 \mathrm{~kg} \mathrm{~N}$ per ha, might increase yield of the Sen Pidao cultivar by $20 \%$ in the 2080 s, relative to the baseline yield. The authors suggest also that irrigation is essential to fully offset the potentially negative impacts of climate change in Cambodia, which arise largely due to projected increases in average temperatures [94]. Farmers in Central Vietnam also might offset the negative impacts of climate change by delaying the planting dates of winter season (rainfed) and summer season (irrigated) rice by about one month and three weeks, respectively [104]. Specific, optimal planting dates vary somewhat across scenarios representing climate change impacts in the 2020s, 2050s, and 2080s. Supplemental irrigation in the winter season also would be helpful in increasing rice yields.

In areas where water supplies become limited, farmers might need to modify their annual production program to include only one or two crops per year, rather than two or three. Where feasible, many farmers might increase their use of nitrogen fertilizer and irrigation to offset the potentially negative impacts of climate change [94,105]. Farmers also might consider changing crop calendars and the varieties of rice they produce, to optimize output in the shifted, and possibly shortened, rice growing seasons $[7,106,107]$. Changes in crops, cultivars, and crop calendars will modify the total costs and net returns in farming and the risks associated with crop production and marketing. Optimizing crop choices and production practices, in response to climate change, will require that farmers acquire new knowledge of production and marketing opportunities. They will also need timely and affordable access to weather forecasts and information regarding enhancements in drought and flood management practices, pest populations, and control measures $[96,100,108]$. 


\subsection{Regional Adaptation Efforts}

Many farmers, input supply firms, and marketing agents will need better information and enhanced training to adapt successfully to climate change $[109,110]$. The information and training programs might be provided by extension service personnel and by representatives of companies engaged in the production and sale of farm inputs, including irrigation equipment, pesticides, plant nutrients, and farm equipment. In some countries, substantial investments in agricultural extension services will be needed to assist farmers in learning how best to adapt to climate change. Participatory programs, such as the Farmer Field Schools introduced by the Food and Agriculture Organization in the 1980s, can be designed to increase farm-level capacity to gather and interpret local and regional information regarding weather, soil moisture, pest populations, nutrient status, and crop responses [111,112]. Adaptive research, in which farmers participate in evaluating proposed changes in production methods also has merit in determining and then disseminating recommendations that will advance adaptation efforts across large agricultural areas [113,114].

Given the uncertain and diverse nature of the impacts of climate change on rice production, regional adaptation efforts might begin with investments in field-level data collection, farmer training, and extension service programs. Stigter et al. [115] recommend investments in extension agrometeorology, which is largely an effort to increase the capacity of farmers to gather and interpret data describing weather conditions, with the goal of enhancing their understanding of the challenges posed by climate change [116,117]. Extension efforts in Indonesia include Climate Field Schools and Science Field Shops, in which farmers interact with scholars to gain insight regarding climate change, adaptation, and data collection methods that farmers can implement at the plot level [118-121].

Investments in regional irrigation and drainage schemes will be needed, where appropriate, to enhance the collection, storage, and distribution of irrigation water and to provide adequate drainage of agricultural lands [122-124]. Investments in flood control structures and flood risk management also will be needed in areas where climate change will increase the frequency and severity of floods $[108,125,126]$. Investments in education, training, and international exchange will be needed to promote optimization of systems that include irrigation, drainage, and flood control components [127,128]. Efforts should be made also to include farmers, business persons, and other residents in the planning process when designing infrastructure investments and developing operational protocols [129].

\subsection{National and International Investments}

Many of the high yielding varieties of rice that are produced currently across large areas of Asia were developed for their high yielding potential, rather than drought tolerance. Thus, much of the rice production in Asia, particularly in rainfed areas, is susceptible to substantial yield reductions in drought conditions $[7,130,131]$. The potential gains from developing drought-tolerant rice varieties are substantial, given the global importance of rice in assuring food security, particularly in Asia and in portions of Africa. Recent experience with drought-tolerant varieties in Asia suggests that the newer varieties generate somewhat higher yields in normal to good rainfall years, while providing some yield protection in moderate drought years [132]. However, in severe drought years, both conventional and drought-resistant varieties have failed to produce a viable crop. Further research and additional support from donors and national governments will be needed to develop better drought-resistant varieties and to achieve successful uptake by farmers [132].

National and international research centers already are engaged in efforts to develop new crop varieties that are tolerant of drought, higher temperatures, more variable rainfall, extended submergence, and salinity $[11,12,14,133]$. Success in developing such varieties will benefit farmers and consumers in many countries. Similar efforts are underway to develop new breeds of livestock that will be more tolerant of higher temperatures [134-137]. Research centers also are developing better methods of understanding the likely impacts of climate change on global and regional weather patterns [138-140]. Such efforts, which generate international public goods, will be helpful in 
developing better methods for predicting changes in weather on a timeframe that might be helpful to farmers and others engaged in agriculture.

Breeding efforts are underway also to identify salt tolerant rice cultivars that might be planted in coastal regions subject to saline intrusion, due partly to climate change [141]. Islam et al. [142] examine several rice varieties developed for use in the wet and dry seasons in the coastal region of Bangladesh. The authors recommend using varieties with higher salt tolerance and shorter duration in the dry season, while using salt tolerant varieties that are also tolerant of stagnant flooding conditions in the wet season. Indeed, the planting of salinity-tolerant rice varieties already is the primary adaptation response for farmers in coastal areas of Bangladesh, where major storms and sea level rise have caused soil and water salinity in rice fields to increase in recent years [75].

A similar strategy might be appropriate for coastal areas of the Mekong Delta in Vietnam, which also are subject to saline intrusion [143-146]. Scientists at the International Rice Research Institute and in several national research centers are developing flood-tolerant varieties with enhanced resistance to submergence $[147,148]$. Sarangi et al. [149] describe the higher productivity achieved with the new rice variety, Amal-Mana, in stagnant flooding conditions in trials conducted on farms and on experiment stations in West Bengal. In addition to producing higher yields, the quality of the grain is superior for cooking and eating, in comparison with traditional rice varieties [149]. Researchers with Kasetsart University and several rice research centers in Thailand have developed a new variety of rice (Hom Mali 821), which is tolerant of flash flooding, moderately resistant to brown planthoppers, and has excellent grain quality [150].

Chun et al. [94] suggest that national investments in agricultural infrastructure, such as irrigation and drainage systems, will be helpful in reducing the negative impacts of climate change on rice yields in Southeast Asia. The authors note, for example, that expanding irrigation schemes in Cambodia to provide service to a larger portion of the country's rice fields, would increase national agricultural productivity, while also enhancing farm-level adaptation to the changes in weather conditions that will accompany climate change. National governments and international donors are well placed also to invest in regional irrigation, drainage, and flood control facilities.

Provinical and national governments also might consider providing or promoting crop insurance for smallholder farmers. Although crop insurance will not modify the technical coefficients that describe the farm-level damage from climate change, it can enable farmers to sustain financial losses with greater likelihood, while also enabling them to invest in new crop varieties and production methods that will enhance their resilience to climate change. Over time, private markets in crop insurance should arise in some settings, although some degree of public oversight might be required to ensure that smallholder farmers can participate successfully in the insurance market. Research will be needed also to determine the best form of insurance to implement in regions where damaging floods might occur with increasing frequency. The compensation payments for damages claimed by farmers holding indemnity policies might easily exceed the premiums paid in some years, particularly if the premiums are subsidized by a government agency [151]. Weather index insurance might be preferable to indemnity insurance in some areas.

The Government of Japan has provided compulsory crop insurance for all of the country's rice farmers for many years [152]. Payments are made to farmers in years when average rice yields are smaller than pre-determined standard yields, which vary by prefecture. Iizumi et al. [152] examined the likely impact of climate change on rice yields and insurance payments in Japan, using downscaled climate change projections for each prefecture to simulate temperature effects, while also accounting for the likely impacts of storms, diseases, and pests. The authors project a 10\% increase in rice yields in the 2070s in Hokkaido, in Northern Japan, due to a significant reduction in damage from cool summer temperatures. Rice yields will decline in the 2070s in Central and Western Japan, due to an increase in heat stress and a reduction in biomass, due to a shortening of the growth period [152]. The authors also project changes in the standard yields that determine the insurance payment benchmarks. Those yields will be higher in the 2070s in Hokkaido and Tokai, where average yields also will increase, but lower 
in all other areas. The resulting simulated insurance payouts are smaller in the 2070s than in the 1990s, in six of the nine regions defined by Iizumi et al. [152] in their analysis. In sum, the annual payout for the national rice insurance program is $13 \%$ smaller in the 2070s than in the 1990s (104.4 billion yen vs. 120.2 billion yen). The authors suggest that adaptation measures, such as changing the planting date or adopting new cultivars, might further reduce the average annual insurance payout [152].

\section{Reducing Methane Emissions}

Flooded rice paddies have been known to be a major source of methane and nitrous oxide, both of which are important atmospheric pollutants, for many years [153-160]). Methane, carbon dioxide, and nitrous oxide contribute an estimated $87 \%$ of total radiative forcing, thus having a notable impact on global warming [161]. Methane is generated in the anaerobic conditions that prevail in flooded rice paddies. Rice production in upland areas, in which the fields are not maintained in flooded conditions, generates substantially less methane per hectare and per unit of rice [162,163].

Changes in soil and water management practices can substantially reduce methane emissions attributed to paddy rice production [164-167]). Among the major cereals, rice production generates higher methane emissions per hectare and per unit of yield than does the production of wheat or maize [168]. The potential reductions in annual methane emissions through improvements in soil and water management are particularly large in areas where two or three crops of rice are produced each year [169].

Methane emissions from rice paddies and other wetland ecosystems likely will increase with climate change, as the increasing atmospheric concentration of $\mathrm{CO}_{2}$ promotes greater root development per unit of biomass produced [170,171]. As rice plants allocate a larger portion of assimilated carbon to roots, the amount of carbon available to methanogenic Archaea in the soil will increase, thus leading to greater generation of methane per unit of rice production [170,171]. Thus, efforts to reduce methane emissions from rice paddies are needed to offset both the necessary increase in rice production to sustain global food security and the $\mathrm{CO}_{2}$-induced increase in methane generation per unit of wetland area $[170,171]$.

\subsection{Intermittent Drainage vs. Continuous Flooding}

Methane generation and release from rice production can be reduced by switching from continuously flooded paddies to a program of intermittent irrigation and drainage, and by limiting the amount of plant residue incorporated into soils after harvest and before planting [172,173]. Small reductions in the time during which rice paddies are inundated can substantially reduce methane emissions. However, switching from anaerobic to aerobic production can create the conditions that support nitrification and denitrification, such that nitrous oxide emissions can increase with the change in water management strategy $[174,175]$. The degree to which methane emissions are reduced and nitrous oxide emissions are increased is largely an empirical issue, which is influenced by soil characteristics and the history of soil and water management in a given location [176]. The timing of irrigation and drainage events in rice paddies also can influence methane and nitrous oxide emissions, while also impacting rice yields [174].

Farmers in Japan have been draining their rice fields in midseason for many years, largely to increase crop yields, by enabling the aeration of roots and by minimizing the excessive growth of ineffective tillers [177]. Following the midseason drainage period, which is about seven to ten days in length, many farmers also practice intermittent irrigation and drainage for the remainder of the season [178,179]. That practice allows for continued root development, while also preventing roots from rotting. In addition, intermittent irrigation and drainage requires less irrigation water than the volume required to maintain continuous flooding $[177,180]$. The enhanced root development also reduces the likelihood of rice plants lodging, as harvest approaches.

The midseason drainage and the subsequent, intermittent irrigation and drainage practiced by Japanese rice farmers have been shown to reduce methane emissions. Yagi et al. [181] observed 
reductions in methane emissions of 42\% and 45\% in 1991 and 1993, respectively, on experimental plots in Kanto Province, Japan, that were drained at least two times during the season. Intermittent drainage was applied twice in 1991 and eleven times in 1993. The authors suggest that the latter program of eleven intermittent drainage events reflects conventional Japanese rice cultivation in the region. There were no significant differences in nitrous oxide emissions or rice yields on the continuously flooded and intermittently drained plots in either year [181]. The authors conclude that water management can be an important methane mitigation measure, provided that rainfall is not excessive and farmers have adequate control of irrigation water deliveries.

Tyagi et al. [182] examined the impacts of midseason and intermittent drainage on methane emissions from rice fields on an experiment station in Lucknow, India, where farmers typically drain their rice paddies once each season, at the tillering stage, to provide oxygen to the roots. The authors compared that practice with continuous flooding, midseason drainage at 70 days after planting, and intermittent drainage involving two drainage events at 21 days and 77 days after planting. The observed seasonal methane effluxes from the plots were 347, 315, 291, and $205 \mathrm{mg} \mathrm{CH}_{4}$ per $\mathrm{m}^{2}$ per day, for the continuous flooding, tillering stage drainage, midseason drainage, and intermittent drainage treatments, respectively. In comparison with continuous flooding, seasonal methane emissions were reduced by $9 \%, 37 \%$, and $41 \%$, respectively, with the selected drainage treatments [182].

Installing subsurface drains beneath rice fields also will aid in reducing methane emissions, particularly in poorly drained areas. Subsurface drains speed the drying process of soils beneath rice fields, thus allowing more oxygen in the root zone and suppressing methanogenic activity [183]. In the 1960s, the Government of Japan implemented a program of land consolidation and investment in infrastructure to increase rice production and enhance national food security. Within that program, subsurface drainage systems were installed beneath many poorly drained rice fields across Japan $[183,184]$. As a result, many rice fields in Japan are equipped with subsurface drainage systems.

Shiratori et al. [183], examined the impacts of a subsurface drainage system on methane emissions in a study involving two rice fields in Niigata Prefecture, where $80 \%$ of the rice fields improved since the 1960s are served by subsurface drains. Methane emissions on the drained field were $71 \%$ less than emissions from the non-drained field. In a similar study involving three pairs of rice fields, also in Niigata Prefecture, Furukawa et al. [184] found that the methane generation potential of drained soils is about $40 \%$ less than the methane generation potential on fields without subsurface drains.

Farmers in China also have adopted the practice of draining their rice fields during the season, primarily to increase yields. The practice of midseason drainage first appeared in Northern China in the early 1980s, and has since replaced continuous flooding over much of the country's rice production area $[185,186]$. In a simulation exercise using the DNDC (DeNitrification-DeComposition) biogeochemical model, Li et al. [185] project that the methane emissions from all of China's paddy rice fields in 1990 might have been within the range of 8.6 to $16.0 \mathrm{Tg} \mathrm{CH}_{4}$ per year, if the fields had been continuously flooded. If the fields had all been drained at midseason, the methane emissions might have been in the range of 2.3 to $10.5 \mathrm{Tg} \mathrm{CH}_{4}$ per year. For the period of 1980 through 2000, the authors project that methane emissions from all of China's paddy rice fields were reduced by $40 \%$ (about $5 \mathrm{Tg} \mathrm{CH}_{4}$ per year), due to the widespread adoption of midseason drainage [185]. For perspective, the estimated methane emissions from all rice fields, globally, during 2000 to 2009 , are within the range of 33 to $40 \mathrm{Tg} \mathrm{CH}_{4}$ per year [187]. Thus, the adoption of midseason drainage by paddy rice farmers in China might have reduced global emissions of methane from rice fields by about $12 \%$ during the decade of 2000 to 2009.

Methane emissions might be reduced further on rice fields cultivated in aerobic conditions throughout the season. Aerobic rice production, which is known also as upland rice production in many settings, is characterized by non-flooded, non-puddled, and non-saturated soil conditions [188]. Rice varieties with drought-resistant, high-yielding characteristics have been developed for use in aerobic production [189-192]. Xue et al. [193] examined alternative irrigation and nitrogen treatments on experimental plots of the aerobic rice variety HD297, in a two-year study conducted near Beijing 
in 2003 through 2004. Irrigation treatments varied by the amount of water applied before and after panicle initiation. Average grain yields on the plots receiving the most irrigation before and after panicle initiation ranged from 2.4 to $4.1 \mathrm{t}$ per ha in 2003 and from 4.8 to $5.7 \mathrm{t}$ per ha in 2004 . Average grain yields on the plots receiving the most irrigation before panicle initiation, but less irrigation later in the season, ranged from 0.8 to $2.5 \mathrm{t}$ per ha in 2003 and from 5.1 to $5.6 \mathrm{t}$ per ha in 2004 . The higher yields in 2004 might be due to more favorable weather conditions, including a more even distribution of rainfall, higher levels of solar radiation, and lower night temperatures than those that were observed in 2003 [193]. Although the authors did not measure methane emissions, the yields obtained in 2004 suggest that aerobic rice production might be a viable alternative to flooded paddy production in some settings.

In a three-year experiment conducted in southeastern Uruguay, with an indica rice cultivar, Tarlera et al. [194] compared the methane and nitrous oxide emissions on rice fields that were flooded continuously from 30 days after emergence (CF30), with fields that were irrigated intermittently from 30 days after emergence through 70 days after emergence (AWDI). The second set of fields was then flooded continuously for the remainder of the season. The mean seasonal methane emissions from the CF30 plots were 208, 249, and $249 \mathrm{~kg} \mathrm{CH}_{4}$ per ha, during each of three crop seasons. The mean seasonal emissions from the AWDI plots were 93, 106, and $96 \mathrm{~kg} \mathrm{CH}_{4}$ per ha, respectively. The differences in the means are statistically significant in years two and three. The mean seasonal emissions of nitrous oxide range from 0.3 to $1.9 \mathrm{~kg} \mathrm{~N}_{2} \mathrm{O}$ per ha, across treatments and years. None of the differences in $\mathrm{N}_{2} \mathrm{O}$ emissions is statistically significant.

The notable reductions in methane emissions, achieved by modifying the irrigation strategy, are associated with reductions in crop yields. In particular, the mean rice yields on the CF30 plots were 11,171, 10,387, and $9803 \mathrm{~kg}$ per ha, during each of three crop seasons, while the mean seasonal yields on the AWDI plots were 10,170, 8700, and $8992 \mathrm{~kg}$ per ha, respectively [194]. The reductions in the mean yields are statistically significant in years two and three. The authors suggest that the reductions in crop yields might be due partly to the particular irrigation treatment, in which water is applied only when $50 \%$ of the available soil moisture has been removed. An alternate wetting-and-drying strategy involving more frequent irrigation might generate meaningful reductions in methane without significantly reducing crop yields.

Wang et al. [164] also examine the potential reduction in methane emissions when modifying the irrigation strategy, in an experimental setting in Nanjing, China. The authors compare emissions from continuously flooded fields (W0), with emissions from fields that are drained twice each season: once for nine days at mid-season, and again for two weeks before harvest (W2). The authors also examine the potential impacts of supplemental nitrogen and the incorporation of rice straw into the soil before transplanting. The mean seasonal methane emissions in 2006 from the W0 and W2 plots were $390 \mathrm{~kg} \mathrm{CH}_{4}$ per ha and $156 \mathrm{~kg} \mathrm{CH}_{4}$ per ha, respectively. The mean emissions from the plots without (S0) and with (S1) straw incorporation were $159 \mathrm{~kg} \mathrm{CH}_{4}$ per ha and $387 \mathrm{~kg} \mathrm{CH}_{4}$ per ha, respectively. Thus, modifying the irrigation strategy reduced seasonal methane emission by about $60 \%$, while the incorporation of straw increased methane emission by $59 \%$. The authors conclude that water management and straw incorporation are equally important factors in determining methane emissions from rice paddies [164].

The irrigation strategy and straw incorporation had no significant impacts on rice yields in the Wang et al. [164] study. By contrast, supplemental nitrogen significantly increased grain yield and straw biomass, while having no impact on methane emissions. Also of interest, any increases in $\mathrm{N}_{2} \mathrm{O}$ emissions that might have been caused by the supplemental nitrogen application of $220 \mathrm{~kg} \mathrm{~N}$ per ha, per crop (N1), were much smaller than the reductions in $\mathrm{CH}_{4}$ emissions achieved by modifying the irrigation strategy, on a carbon dioxide equivalent basis. In particular, the mean reduction in $\mathrm{CH}_{4}$ emissions, across combinations of the $\mathrm{S} 0, \mathrm{~S} 1, \mathrm{~N} 0$ (no supplemental nitrogen), and N1 treatments is about $5869 \mathrm{~kg} \mathrm{CO}_{2}$-equivalents per ha, while the mean increase in $\mathrm{N}_{2} \mathrm{O}$ emissions is about $24 \mathrm{~kg}$ $\mathrm{CO}_{2}$-equivalents per ha [164]. Thus, it might be possible to offset some of the potential yield reduction 
due to modifying the water management program by applying supplemental nitrogen, without substantially increasing nitrous oxide emissions, on a $\mathrm{CO}_{2}$-equivalent basis.

About $40 \%$ of China's rice production area is found in the middle reaches of the Yangtze River, where many farmers cultivate paddy rice in rotation with rapeseed. Xu et al. [195] examine the implications of alternative water management practices on methane generation during the rice production season and also during the subsequent rapeseed production season. The authors compare continuous flooding of rice paddies (CF) with initial flooding and intermittent wetting and drying (FWI), and with initial flooding and only limited irrigation during drought conditions and when fertilizer is applied (RFL). In the RFL treatment, the rice plants rely largely on rainfall. Both the FWI and RFL irrigation methods reduced methane emissions during the rice season, while increasing the emissions of nitrous oxide and carbon dioxide. Water management strategies in the subsequent rapeseed season further reduced emissions of methane and nitrous oxide on the FWI and RFL plots, while having no further impact on carbon dioxide emissions. Thus, the FWI and RFL treatments generated significant reductions in annual global warming potential, when considering the full cycle of the rice-rapeseed rotation [195].

Pandey et al. [196] compare methane and nitrous oxide emissions on rice fields irrigated intermittently (AWD) with emissions on continuously flooded fields (PF), in a single-season experiment in Hanoi, Vietnam. The authors also examine the potential impacts of several soil amendments, including animal manure, aerobically composted rice straw, and biochar produced from rice straw. The AWD plots were continuously flooded for 24 days after transplanting. Irrigation was then discontinued until moisture receded to a depth of $15 \mathrm{~cm}$ below the soil surface. At that time, irrigation was applied to achieve a 3 to $7 \mathrm{~cm}$ water level above the soil surface. This cycle of wetting and drying was continued until 15 days before harvest, with the exception of continuous flooding during the flowering stage, which occurred from 62 to 76 days after transplanting. In sum, three irrigations were applied on the AWD plots, at 37,48 , and 58 days after transplanting.

Statistically significant reductions in methane emissions and significant increases in nitrous oxide emissions were observed on the AWD plots, largely across the soil amendment treatments [196]. The mean annual methane emissions ranged from 108 to $353 \mathrm{~kg} \mathrm{CH}_{4}$ per ha on the PF plots, while declining to a range of 31 to $105 \mathrm{~kg} \mathrm{CH}_{4}$ per ha on the AWD plots. The mean annual nitrous oxide emissions ranged from 0.27 to $0.44 \mathrm{~kg} \mathrm{~N}_{2} \mathrm{O}$ per ha on the PF plots, while increasing to a range of 0.67 to $0.97 \mathrm{~kg}$ $\mathrm{N}_{2} \mathrm{O}$ per ha on the AWD plots. Methane emissions were lowest on plots with no soil amendments, followed by those amended with biochar. Animal manure and composted straw generated higher methane emissions on both the PF and AWD plots.

There were no significant yield effects due to any of the treatments in the Pandey et al. [196] study. Mean rice yields ranged from 5250 to $6020 \mathrm{~kg}$ per ha. As in the results reported by Wang et al. [164], the increase in nitrous oxide emissions due to the change in irrigation strategy was much smaller than the reduction in methane emissions, on a $\mathrm{CO}_{2}$-equivalent basis. Thus, the global warming potential of rice production was significantly reduced by switching from continuous flooding to intermittent irrigation in the Pandey et al. [196] study, both on a per hectare basis and per unit of rice yield. In particular, the estimated global warming potential ranged from 2784 to $8956 \mathrm{~kg} \mathrm{CO}_{2}$-equivalents per ha for the PF treatments, while declining to a range of 1005 to $2911 \mathrm{~kg} \mathrm{CO}_{2}$-equivalents per ha for the AWD treatments. Similarly, the global warming potential ranged from 510 to $1490 \mathrm{~kg} \mathrm{CO}_{2}$-equivalents per ton of rice for the PF treatments, while declining to a range of 197 to $544 \mathrm{~kg} \mathrm{CO}_{2}$-equivalents per ton for the AWD treatments.

\subsection{Soil Amendments and Tillage}

Methane is formed in rice paddies as methanogens (anaerobic Archaea) decompose carbonaceous materials in the soil. Thus, carbon sources, such as animal manure, rice straw, and other plant residues enhance methane generation in rice paddies [197-199]). In some deltaic areas, many farmers produce two or three crops of rice per year, often relying on irrigation to support the second and third crops. 
Soil and water management of the rice fields, between crops, can be helpful in reducing methane releases during the subsequent rice season. Sander et al. [200] examined water management and tillage treatments between the wet and dry season rice crops on an experiment station in Los Baños, Philippines. The treatments included continuous soil flooding (flooded), soil drying by excluding rainfall (dry), and soil drying, with two tillage events (dry + tillage). The authors also examined the effects of incorporating or removing the plant biomass after harvest.

Methane emissions were significantly higher in the second season on fields with incorporated residue, than on fields from which the residue had been removed. Methane emissions were higher also on fields that were flooded during the fallow period, than on fields that were kept dry or were dried and tilled. Cumulative methane emissions, averaged over all fallow management treatments, were about twice as large on the fields with incorporated residue, than on those from which the residue had been removed [200]. The sum of methane emissions across both seasons was smaller for the dry and dry + tillage treatments, than for the flooded treatment. Nitrous oxide emissions were small in both seasons, and were not influenced by the flooding or tillage treatments. Rice yields were higher in the dry season than in the wet season. Yields were not influenced by soil and water management during the fallow period. In sum, maintaining rice fields in dry condition and removing plant biomass reduced methane emissions in the subsequent season. Further study is needed to determine the longer-term impacts of removing the plant biomass, which is an important source of carbon and potassium [200].

Ly et al. [201] examined the potential impacts of replacing rice straw with biochar, as a helpful soil amendment, in a controlled environment growth chamber study using soil from a rice production area in Cambodia. The authors also compared continuous flooding with a strategy of alternate wetting and drying. Supplemental nitrogen in mineral fertilizer was added in all treatments. Methane emissions were highest on plots treated with rice straw, followed by those treated with biochar. The lowest methane emissions were observed on plots with no soil amendment. On the soil amended plots, methane emissions were lower with alternate wetting and drying, than with continuous flooding. Methane emissions were higher with alternate wetting and drying, than with continuous flooding, on the treatments with no soil amendment. Nitrous oxide emissions were largely non-detectable during the experiment, when applying nitrogen fertilizer. Rice yields were slightly higher in the alternative wetting and drying treatments [201].

Pratiwi and Shinogi [202] also have examined the use of biochar to reduce methane emissions in rice production. In an outdoor pot experiment with two application rates, methane emissions were reduced by $45 \%$ and $55 \%$ when biochar was applied at the rates of $2 \%$ and $4 \%$ of the weight of soil in the pots. Mohammadi et al. [203] compared conventional residue management on rice fields (System A) with the practice of applying biochar to the fields (System B). The biochar was created by collecting the rice straw, rather than burning it in the field, and pyrolysing the straw with wood in an updraft oven. Rice husks were collected after milling, and were processed with wood in a pyrolitic cook-stove. The estimated carbon footprints of the rice produced in System A were 1.49 and $4.50 \mathrm{~kg} \mathrm{CO}$-equivalents for the spring and summer seasons, respectively. Most of the carbon footprint (87\% in spring and $94 \%$ in summer) was comprised of methane emissions. By comparison, the estimated carbon footprints of the rice produced in System B were 49\% and 38\% smaller than those observed in System A. The smaller carbon footprints were attributed largely to stabilization of carbon in the biochar and reductions in methane emissions [203].

While incorporating plant residue in rice paddy soils generally increases methane generation, incorporation of selected portions of plant residue might provide agronomic benefits, while not increasing methane emissions. Penido et al. [204] examined the incorporation of fresh rice straw (FS), fresh rice husk ( $\mathrm{FH})$, rice straw ash (RSA), and rice husk ash (RHA), at the rate of $1 \%$ of the weight of soil, in a flooded pot experiment. Soils amended with the fresh materials (FS and FH) had higher levels of dissolved silicon than those amended with the ash materials (RSA and RHA), while the FS-amended soil had the highest concentrations of arsenic, iron, and methane. The authors conclude that amending soils with FH, RSA, or RHA might enable smallholder rice farmers to increase plant-available silicon, 
while not causing higher levels of methane emissions [204]. Although silicon is not considered an essential element, it has been shown to reduce biotic and abiotic stresses, including arsenic uptake and toxicity [205-214].

Sui et al. [215] examined the use of biochar created from rice straw in a two-year experiment on continuously flooded rice paddies at the Shenyang Agricultural University in Liaoning Province, China. Treatments included rice straw applied at $5.05 \mathrm{t}$ per ha (S), and biochar applied at the rates of $1.78 \mathrm{t}$ per ha (B1), $14.8 \mathrm{t}$ per ha (B2), and $29.6 \mathrm{t}$ per ha (B3). Control plots received no straw or biochar as a soil amendment. The authors also examined two rates of nitrogen fertilizer: $0 \mathrm{~kg} \mathrm{~N}$ per ha (N0) and $210 \mathrm{~kg} \mathrm{~N}$ per ha (N1). Total methane emissions were highest on the plots receiving straw at $5.05 \mathrm{t}$ per ha. The biochar amendments reduced methane emissions, relative to the straw treatment, for both levels of nitrogen. Biochar also increased total soil carbon at higher rates than returning straw to the soil. The carbon in biochar can exist in soils over long time scales, and biochar increases soil porosity, while reducing soil bulk density [216].

Changing the cropping pattern from continuous paddy rice to paddy rice followed by maize or aerobic rice production can substantially reduce methane emissions. Weller et al. [217] examined methane and nitrous oxide emissions from three cropping patterns on experimental plots in Los Baños, Philippines. Replacing the second paddy rice crop with an upland crop (maize or aerobic rice) reduced methane emissions by $66 \%$ to $81 \%$. Methane emissions were reduced also in the subsequent wet season, when paddy rice was again planted, by $54 \%$ to $60 \%$. Annual emissions of nitrous oxide increased with the planting of an upland crop, yet the substantial reductions in methane emissions resulted in a smaller global warming potential with the diversified cropping pattern [217].

Zhang et al. [218] also examine methane and carbon dioxide emissions from fields planted in a rice-rapeseed rotation in Central China. The authors assess the implications of alternative tillage practices and of incorporating plant residue into the soil, following harvest. Returning plant residue to the field increased rice grain yields by $38 \%$ and $32 \%$ on plots receiving $3000 \mathrm{~kg}$ per ha and $6000 \mathrm{~kg}$ per ha of plant residue, respectively. Tillage practices did not influence rice yields, but they did have an impact on methane and carbon dioxide emissions. In particular, yield-adjusted emissions of methane and carbon dioxide, expressed as $\mathrm{kg}$ of $\mathrm{CO}_{2}$-equivalents per $\mathrm{kg}$ of rice grain yield, were reduced by $16 \%$ on non-tilled plots, in comparison with conventional tillage. Returning $3000 \mathrm{~kg}$ per ha or $6000 \mathrm{~kg}$ per ha of plant residue did not influence methane and carbon dioxide emissions. Across all treatments, the combination of non-tillage and returning $3000 \mathrm{~kg}$ per ha of plant residue generated a relatively large, average rice yield (7325 $\mathrm{kg}$ per ha), with the lowest observed values of yield-adjusted methane and carbon dioxide emissions [218].

\subsection{Direct Seeding vs. Transplanting}

Most of Asia's rice fields are started by transplanting seedlings into puddled soil on land that has been prepared with wet tillage [219]. Puddling facilitates easy seedling establishment, but transplanting into flooded soils requires large volumes of water and substantial labor. In areas with increasing scarcity of both labor and water, direct seeding of rice, as an alternative to puddled transplanting, has gained favor among rice farmers $[219,220]$. Direct seeding into either wet or dry soil has the potential also to reduce methane emissions, as the rice paddies are flooded for a shorter period, than when transplanting into puddled fields. Kumar and Ladha [219] review many studies in which the methane emissions from direct seeded fields are compared with those from puddled, transplanted fields. In comparison with puddled transplanting on fields cultivated with continuous flooding, direct seeding into dry soils reduced methane emissions by $24 \%$ to $79 \%$, while direct seeding into wet soils reduced methane emissions by $8 \%$ to $22 \%$. Although nitrous oxide emissions increase with direct seeding into dry soils, the global warming potential tends to be lower for that method than for puddled transplanting, given the large reduction in methane emissions achieved with direct seeding [219].

Pathak et al. [221] measured the methane and nitrous oxide emissions from direct seeded (DSR) and transplanted (TPR) rice on nine experimental plots in the Jalandhar District of Punjab, India in 2009 
and 2010. The TPR plots were continuously submerged during the season, at a depth of about $4 \mathrm{~cm}$, while the DSR plots were submerged only on the days when irrigation was provided. The TPR plots received 21 to 22 and 15 to 16 irrigations in 2009 and 2010, respectively, while the DSR plots received 14 to 16 irrigations in 2009 and 12 to 13 irrigations in 2010. The smaller numbers of irrigations in 2010 reflect the more uniform distribution of rainfall received in that year. Methane emissions from the DSR plots ranged from 0.6 to $1.5 \mathrm{~kg}$ per ha in 2009 and from 4.2 to $4.9 \mathrm{~kg}$ per ha in 2010, while methane emissions on the TPR plots ranged from 42.4 to $57.8 \mathrm{~kg}$ per ha in 2009 and 56.0 to $56.5 \mathrm{~kg}$ per ha in 2010. Nitrous oxide emissions were similar on the DSR and TPR plots, ranging from 0.9 to $2.2 \mathrm{~kg}$ per ha, across treatments and years. Rice yields and yield attributes also were similar across treatments, while labor use and tractor hours were reduced by about $50 \%$ on the DSR plots [221].

Direct seeding of rice has been practiced for many years in the Mekong Delta of Vietnam, where farmers appreciate the smaller labor requirement, the shorter time required to establish the rice crop, and the smaller water requirement, in comparison with transplanting seedlings from a nursery [222]. In a survey of 102 farm households in three districts of Can Tho Province, participants reported grain yields ranging from 6270 to $7310 \mathrm{~kg}$ per ha in 2012 and from 6790 to $8850 \mathrm{~kg}$ per ha in 2013, with profits ranging from USD 658 to 1184 per ha in 2012 and from USD 758 to 1268 per ha in 2013, on direct seeded rice fields [222]. Managing weeds is a time consuming and costly effort when seeding the fields directly, but the yields and profits reported in the survey are among the highest observed in Asian rice production settings [222]. Weed management strategies include manual and mechanical weeding, the use of herbicides, and rotating herbicides with manual or mechanical weeding [223]. Adjustments in row spacing and in the timing of weeding operations also can influence weed growth and rice yields [224]. Using weed-free rice seeds and clean machinery also are essential practices when directly seeding rice fields [225].

Direct seeding of rice has been practiced in Sri Lanka since the 12th century [226]. Transplanting gained some popularity in the 1960s, when farmers gained access to transplanting technology, but most farmers have since resumed their reliance on direct seeding. In 2008, more than 95\% of Sri Lanka's rice fields were direct seeded [226]. Most of the 202 farmers interviewed by Weerakoon et al. [226] practice wet seeding, in which pre-germinated seeds are broadcast on puddled, leveled fields that are free from standing water. In areas where water availability is limited or when initial rains are delayed, farmers practice dry land preparation. More than $90 \%$ of the farmers who use direct seeding describe the savings in time, labor, and expenditures, in comparison with transplanting, as desirable aspects of the program. As in other countries, weed control is a primary concern of farmers using direct seeding in Sri Lanka [226,227].

Farmers in the Indian state of Punjab also have used direct seeding for several centuries, yet the practice of transplanting rice gained popularity during the Green Revolution [228]. As in Sri Lanka, many farmers in Punjab have returned to direct seeding in recent years, due largely to the increasing cost of transplanting rice, as a result of increasing scarcity of water and labor. Most of the 320 farmers interviewed by Mahajan et al. [228], across all of six of the Punjab's agro-climatic zones, report using either a pre-emergent or post-emergent herbicide to control weeds. However, about $60 \%$ of those farmers report using inadequate water when preparing herbicide applications and using incorrect nozzles when applying the material. Thus, $42 \%$ of the farmers report weeding their fields manually, in addition to using herbicides for weed control [228]. As in other countries, weed management is the primary obstacle to achieving and sustaining high yields when direct seeding rice in Punjab.

\subsection{System of Rice Intensification}

The system of rice intensification (SRI) was introduced in the 1990s as a set of ideas regarding soil, water, and nutrient management designed to generate higher rice yields with fewer inputs [229-231]. In particular, SRI production strategies generally involve fewer rice plants per hectare, less irrigation water applied, and the use of inorganic fertilizer, such as animal manure [232]. One notable feature of SRI production is the switch from anaerobic to aerobic conditions, in which the soil is oxygenated 
for longer periods than when rice is produced in flooded paddies. The oxygen, in combination with the inorganic fertilizer, enhances the activity of soil biota, thus promoting stronger root development and healthier rice plants, resulting in higher yields per hectare in some cases [233,234]. The aerobic characteristic of SRI production is consistent with efforts to reduce methane emissions. Widespread switching from anaerobic to aerobic rice production might greatly reduce aggregate methane generation in some regions. However, the farm-level economics of SRI production must be positive, to support widespread adoption [235].

Ly et al. [236] compare rice yields and methane emissions on fields managed in conventional fashion (CMP) and those managed in accordance with the system of rice intensification (SRI) in a farmer field trial in a rainfed, lowland rice production area in Cambodia, during the wet season. In the SRI treatments, the rice paddies were kept saturated for two weeks after transplanting, followed by alternate wetting and drying. The authors also compared the use of mineral fertilizer with the use of animal manure, which is the preferred form of soil amendment in the SRI strategy. The treatments included animal manure alone (FYM), mineral fertilizer alone (MF), and the combination of both materials $(\mathrm{FYM}+\mathrm{MF})$.

The largest methane emissions were observed on the FYM + MF plots, under both the CMP (282 $\mathrm{kg} \mathrm{CH}_{4}$ per ha) and SRI (213 $\mathrm{kg} \mathrm{CH}_{4}$ per ha) regimes. Methane emissions generally were lower on the SRI plots than on the CMP plots, across the fertilizer treatments. Reductions ranged from $17 \%$ on the MF plots to $24 \%$ on the FYM + MF plots. There was no impact of water management practices on the non-fertilized control. Nitrous oxide emissions were below detection limits on all treatments, and there were no significant yield effects. Thus, the practice of SRI, in combination with mineral fertilizer, might be helpful in reducing methane emissions, while not increasing nitrous oxide emissions or reducing rice yields, in rainfed, lowland areas of Cambodia.

Jain et al. [237] examined the impacts of SRI and a modified version of SRI on methane and nitrous oxide emissions in a field study conducted at the Indian Agricultural Research Institute in New Delhi, in 2009. The treatments differed by the method of transplanting and the frequency of irrigation events. In the conventional transplanting treatment (TPR), two to three 30-day old seedlings were planted per hill, at a spacing of 15 by $20 \mathrm{~cm}$. In the SRI and modified SRI treatments (MSRI), one seedling was planted per hill, at a spacing of 25 by $25 \mathrm{~cm}$. Seedling age was 12 days in the SRI treatment and 18 days in the MSRI treatment. The TPR plots were irrigated every second day, with $5 \mathrm{~cm}$ of water, to maintain saturated moisture conditions. The SRI and MSRI plots were irrigated twice per week, with $3.5 \mathrm{~cm}$ of water, to maintain adequate moisture conditions. Seasonal methane emissions were $61 \%$ and $64 \%$ less on the SRI and MSRI plots, respectively, than on the TPR plots. Seasonal nitrous oxide emissions increased by an average of $23 \%$ on the SRI and MSRI plots, yet the global warming potential was reduced by $28 \%$ and $30 \%$ on the SRI and MSRI plots, respectively. Grain yields were reduced by $4.4 \%$ and $2.2 \%$ on the SRI and MSRI plots, but the reductions were not statistically significant [237].

Suryavanshi et al. [238] conducted a similar experiment, also at the Indian Agricultural Research Institute in New Delhi, during the rainy season of 2010. Conventional transplanting of 21-day old seedlings was compared with SRI production of 12-day old seedlings. The seasonal methane emissions were 32.3 and $19.9 \mathrm{~kg} \mathrm{CH}_{4}$ per ha for the conventional and SRI production methods, respectively. The estimated global warming potentials were 807.5 and $498.2 \mathrm{~kg} \mathrm{CO}$-equivalents per ha, while the average grain yields were 4530 and $5030 \mathrm{~kg}$ per ha, respectively. Thus, the SRI plots produced a significantly higher grain yield, while reducing the global warming potential by about $38 \%$. The conventional plots received 18 irrigations $(1170 \mathrm{~mm})$, while the SRI plots received 12 irrigations (850 mm) [238].

\section{Reducing Arsenic Uptake}

Arsenic occurs naturally in soils and aquifers in many areas of the world $[239,240]$. In some areas, and in some agricultural settings, the concentrations of arsenic in soils and groundwater pose a substantial risk to human health [241,242]. Arsenic has been known to cause cancer in humans 
since the late 19th century. Early evidence pertained to the inhalation of arsenic, while evidence regarding cancer due to arsenic in drinking water appeared in the 1930s [243]. In the 1960s, arsenic was cited as a possible cause of lung and urinary tract cancers in Argentina [243]. Reports of skin lesions and hepatomegaly due to persistent use of drinking water with high concentrations of arsenic in West Bengal appeared in the 1980s [244,245]. In more recent years, several authors have described health effects including skin lesions, respiratory disease, impaired cognition, and cancer due to arsenic exposure in Bangladesh and other countries [241,246-249]).

The concentration of arsenic in much of the water drawn from shallow wells in Bangladesh exceeds the World Health Organization drinking water standard of $10 \mu g$ per liter [245,250,251]. Given the prevalence of shallow wells in Bangladesh and other countries of South and Southeast Asia, an estimated 50 to 100 million persons are at risk of drinking water contaminated with arsenic [252-254]. Acharyya and Shah [255] report that 9.5 million persons have been affected by high concentrations of arsenic in drinking water in nine districts in southern West Bengal. Based on an extensive, 14-year study of tubewells in Bangladesh, Chakraborti et al. [256] suggest that as many as 36 million and 22 million residents might be drinking water from wells with arsenic concentrations in excess of $10 \mu \mathrm{g}$ per liter and $50 \mu \mathrm{g}$ per liter, respectively. The latter concentration is the current national drinking water standard for arsenic in Bangladesh, which several authors suggest is not sufficiently restrictive [257-259].

\subsection{Extent of the Problem}

Arsenic is found in soils and groundwater across large portions of the major river deltas in South and Southeast Asia. To date, arsenic contaminated groundwater has been found in Bangladesh, India (West Bengal), Cambodia, Myanmar, and Vietnam [260]. The original source of the arsenic is the Himalayan mountain range, where arsenic-laden rocks have weathered and eroded, over thousands of years, thus releasing arsenic into the major river systems, including the Ganges-Brahmaputra, Irrawaddy, Chao Phraya, Mekong, and Red [260]. The development of irrigation in the river deltas has caused the mixing of arsenic between shallow and deeper aquifers, while also increasing the load of arsenic in agricultural soils $[260,261]$.

Within the lower Mekong region, notable areas with elevated concentrations of arsenic in groundwater have been reported in Cambodia and Vietnam, while too few data are available to characterize the arsenic situation in Laos and Myanmar [262-267]. In Thailand, there is little evidence of naturally occurring arsenic in groundwater, but some areas are impacted by arsenic from mining operations [265]. Sampson et al. [268] suggest that as many as 100,000 persons are at high risk of arsenic exposure in Kandal Province, Cambodia, where arsenic concentrations in tubewells are particularly high [269-271]). All of the 46 wells examined in Kandal Province by Phan et al. [272] had arsenic concentrations in excess of $50 \mu \mathrm{g}$ per liter. More than $10 \%$ of the 40,000 wells surveyed by Vietnam's Department of Water Resources Management during 2002 to 2008, and considered by Erban et al. [273] in their study of arsenic in the multi-layered aquifer system in the Mekong Delta, had arsenic concentrations in excess of the World Health Organization's drinking water standard of $10 \mu \mathrm{g}$ per liter.

Millions of residents in South and Southeast Asia also are at risk from consuming rice with elevated arsenic concentrations in the grain. Among food crops, rice is notably efficient at accumulating arsenic [274,275]. Su et al. [276] report that rice takes up arsenite at twice the rate of wheat or barley. By comparison, the uptake of arsenate was similar for rice and wheat, but one-third less for barley. The condition in which rice is produced contributes to the potential for arsenic uptake and accumulation. Much of the world's rice is produced in paddies that are flooded to a depth of several centimeters for a large portion of the growing season. In anaerobic conditions, metal-reducing microbes transform arsenic into a mobile form that becomes available for uptake by the rice plants [277-279]. In areas where farmers irrigate rice paddies with arsenic tainted groundwater, the uptake of arsenic is enhanced [275].

Arsenic concentrations in rice fields can increase, over time, due to long-term irrigation with arsenic tainted groundwater. Concentrations also can vary substantially across an irrigated region, due 
partly to the initial distribution of arsenic, the variation in aquifer characteristics, and also to the mixing and cycling of arsenic that occurs with pumping of groundwater and the delivery of irrigation water across canal systems and farm fields [253,280-282]. In some areas, arsenic concentrations are higher in shallow wells than in deeper wells, such that some authors suggest preserving deeper aquifers for use as drinking water supplies, rather than extracting deeper water for use in irrigation [253]. Stroud et al. [283] observed substantial temporal and spatial variation in arsenic concentrations in soil and water in a small sample of paddy fields at four sites in Bangladesh and West Bengal. The concentrations of arsenic in grain varied within rice fields, and the variance could not be explained by variation in arsenic concentrations in soil. The authors conclude that arsenic behavior in soil pore water and standing water in rice fields is dynamic and complex [283].

Arsenic also poses a risk to rice plant performance. High arsenic concentrations can contribute to the development of straighthead disease, which can cause sterility after heading, in otherwise healthy rice plants [284]. Panaullah et al. [285] observed a grain yield gradient on a rice field irrigated from a tubewell for 16 years in Bangladesh. During two crop seasons, grain yields declined from about $8000 \mathrm{~kg}$ per ha to $2500 \mathrm{~kg}$ per ha, as the concentration of total arsenic in the soil, across the field, increased from about $12 \mathrm{mg}$ per $\mathrm{kg}$ to $70 \mathrm{mg}$ per $\mathrm{kg}$. The yield decline was associated with a decrease in the number of productive tillers. The authors note, also, that while arsenic concentrations in the rice grain were relatively high, ranging from $0.3 \mathrm{mg}$ per $\mathrm{kg}$ to $0.6 \mathrm{mg}$ per $\mathrm{kg}$, concentrations in rice straw were much higher, ranging from about $2 \mathrm{mg}$ per $\mathrm{kg}$ to $12 \mathrm{mg}$ per $\mathrm{kg}$ [285].

High concentrations in rice straw raise additional concerns regarding arsenic exposure, as rice straw is the primary feed material for cattle and buffalo in Bangladesh, and manure is burned in kitchens to provide fuel for cooking [285]. Ghosh et al. [286] report high concentrations of arsenic in drinking water and rice straw, and in cow's urine, dung, and milk in areas of Bangladesh with high concentrations of arsenic in groundwater. Arsenic concentrations in rice straw were higher in the Boro (dry) season, than during Aus or Aman. Concentrations were higher also in straw irrigated with water from shallow wells, rather than deeper wells. The authors suggest that the arsenic concentrations in milk might be harmful in areas where residents are exposed also to other sources of arsenic, such as drinking water and food, and that household burning of cow dung might become an environmental issue in Bangladesh [286].

Duxbury and Panaullah [287] describe three alternatives for sustaining rice production in areas with high concentrations of arsenic in groundwater, while not increasing human exposure to arsenic in rice:

1. Where possible, irrigate with surface water, rather than groundwater,

2. Cultivate rice in aerobic conditions, rather than flooding rice fields for the entire season, and

3. Where available, produce cultivars that have lower rates of arsenic accumulation.

Irrigating with surface water will reduce arsenic loading to soils, over time, yet arsenic uptake likely will continue in the near term, if rice is produced in anaerobic conditions [288,289]. Switching from flooded paddies to aerobic production can substantially reduce arsenic uptake in the near term [290,291]. The option of producing cultivars with lower rates of arsenic uptake depends partly on the success of rice breeding programs in developing such cultivars, which also must match farm-level and market-driven criteria for successful production and sale. Mitigation measures might also include reducing the amount of straw and other organic matter incorporated into rice soils, in arsenic problem areas, as microbes utilizing the additional organic matter consume oxygen, thus leading to a decrease in redox potential, which furthers the process of arsenic dissolution from iron oxides [292].

\subsection{Water Management}

In areas with high concentrations of both arsenic and cadmium in agricultural soils, choosing a water management strategy requires consideration of both elements. In some soils, the anaerobic 
conditions that characterize paddy rice production can promote the uptake of arsenic, while minimizing the uptake of cadmium [293-295]. Switching from anaerobic to aerobic production can have the opposite effect of minimizing arsenic uptake, while making cadmium more available to plants. The direction and magnitude of the uptake responses of arsenic and cadmium likely will vary with rice cultivars [293,294].

Arsenic uptake in rice can be reduced by switching from a program of continuous flooding to one of alternate wetting and drying. Linquist et al. [296] compared arsenic uptake on experimental plots in the southern United States, in a two-year study involving rice-rice (RR) and rice-soybean (RS) rotations. The irrigation treatments included continuous flooding (flooded control) and three versions of alternative wetting and drying: AWD/40F, AWD/60, and AWD/40. The numbers following the AWD designation represent the proportion of saturated volume at which the fields were re-flooded, after drying. In the AWD/40F treatment, the fields were managed in the same manner as the AWD/40 treatment, until the plants reached the reproductive stage. From that time forward, flooding was maintained until the field was drained for harvest [296].

The highest arsenic levels were observed in the flooded control and the AWD/40F treatments. Arsenic concentrations were reduced, on average, by $56 \%$ on the AWD/60 and AWD/40 treatments, in comparison with the flooded control. Regarding crop rotations, arsenic concentrations in rice grain were $20 \%$ higher, on average, in the RR rotation, in comparison with the RS rotation [296]. Across years and rotations, the highest grain yields were obtained on the flooded control and the AWD/40F treatments. Yields on the AWD/60 plots were similar to the control at two sites, but lower than the control at one site in one year. Average yields were reduced by about $13 \%$ on the AWD/40 plots, which received the smallest volume of irrigation water. The authors note that the AWD/40 treatment would not be desirable, as the AWD/60 treatment achieved a similar reduction in arsenic concentration (and methane emissions), while providing a higher yield [296].

Spanu et al. [291] compared arsenic uptake by rice on a field that was continuously flooded with a field on which sprinklers were used to deliver the irrigation water, at the University of Sassari in Sardinia, Italy. The authors observed substantial reductions in arsenic uptake on the sprinkler irrigated field. Some of the arsenic concentrations in the field approached background levels of arsenic in the irrigation water, leading the authors to suggest that very little bioaccumulation of arsenic might occur in the aerobic conditions maintained by irrigating rice with sprinklers. The authors note also that arsenic uptake varied across the 37 cultivars they examined, both on the flooded and sprinkler irrigated fields.

Moreno-Jiménez et al. [297] also observed substantial reductions in arsenic uptake when irrigating rice with sprinklers, in comparison with continuous flooding. During a seven-year experiment conducted in Spain, concentrations of inorganic arsenic in rice grain were up to two times higher on flooded plots. Concentrations of organic arsenic also were higher on flooded plots, but the difference was not as substantial. Similar grain yields of about $3000 \mathrm{~kg}$ per ha were obtained on both the flooded and sprinkler irrigated plots. Cadmium uptake in rice was substantially higher when irrigating with sprinklers. Cadmium concentrations in rice grain reached $50 \mu \mathrm{g} \mathrm{Cd}$ per $\mathrm{kg}$ during the course of the seven-year experiment on the sprinkler irrigated plots [297].

These results suggest that sprinkler irrigation is effective in reducing arsenic uptake in rice. However, the full cost of purchasing, maintaining, and operating a sprinkler system likely is excessive for many smallholder farmers. A more affordable alternative for reducing arsenic uptake in many areas of South and Southeast Asia is to produce rice in raised beds, and delivering irrigation water in furrows. Talukder et al. [288] observed substantial reductions in arsenic uptake on rice fields panted in permanent raised beds and irrigated in the furrows (PRB), in comparison with continuously flooded, flat fields (CTF) during a two year experiment in the arsenic-affected area of Gaibandha, Bangladesh. Arsenic uptake in both the grain and straw was significantly higher in the CTF plots than in the PRB plots. Specifically, the arsenic concentrations in grain and straw were about three times and seven times higher, respectively, in the CTF plots than in the PRB plots. The authors also observed significant 
increases in grain and straw yields, in both the Boro (dry) and Aman (wet) seasons. About 30\% less irrigation water was applied on the PRB plots, thus notably reducing the amount of arsenic added to soils. In sum, the combination of raised beds and furrow irrigation reduced arsenic input to soils and arsenic uptake, while also improving grain and straw yields [288]. Further research is needed to fully understand the opportunities and challenges inherent in switching from continuous flooding to raised bed planting of rice in Asia [298].

Further research is needed, also, regarding the potential long-term implications of producing rice on raised beds. Singh et al. [299] observed declining yields of transplanted and direct seeded rice on permanent raised beds in a rice-wheat cropping system in Punjab, India. Root knot nematodes became established in the transplanted raised beds, while rice plants on the direct seeded raised beds suffered from severe iron deficiency. Kukal et al. [300] compared the soil bulk density profiles of permanent raised beds, with those of freshly formed raised beds, in a farm field near Punjab Agricultural University. The authors also measured the root mass density of rice plants in $5 \mathrm{~cm}$ increments of soil depth. Root mass density was significantly higher in the upper $15 \mathrm{~cm}$ of soil on the fresh beds. Soil compaction was evident along the edges of the permanent beds, but not along the fresh beds. The authors suggest that the soil compaction on permanent beds might be caused by tractor tires passing through the furrows during the bed re-shaping operations that occur after harvest, each year [300].

Kreye et al. [301] observed significant yield damage due to root knot nematodes on plots of direct seeded and transplanted rice cultivated in aerobic conditions in Central Luzon, Philippines. Pre-treatment of soil with the biocide dazomet reduced root galling due to nematodes on both the direct seeded and transplanted plots. In addition, rice yields were higher on the dazomet treated plots. The authors suggest that soil $\mathrm{pH}$ also might have had a role in generating the observed results, yet further study is needed, regarding the role of soil $\mathrm{pH}$ in the context of nematode damage, and the mechanism by which soil $\mathrm{pH}$ changed during the course of their experiment [301]. In a companion paper, the authors suggest that the use of irrigation water from shallow tubewells might have increased the soil $\mathrm{pH}$, thus inducing micronutrient deficiencies [302]. The authors suggest also that further research is needed, regarding the role of micronutrients, especially iron and manganese, in contributing to the sharp reductions in yield and in the yield failures observed on aerobic rice fields in the tropics [303].

\subsection{Silicon in Soils}

Arsenic uptake in rice can be reduced also by applying silicon fertilizer to increase the availability of silicon in rice paddy soils. Rice is an efficient accumulator of silicon, just as it is of arsenic [214]. Arsenite, the most prevalent form of arsenic in flooded rice paddies, is a silicic acid analogue, and is taken up by rice roots due to its similarity to silicic acid [205,206,214,304,305]. Several authors have shown that when excess silicon is available in the soil or in hydroponic culture, arsenic uptake and translocation to plant shoots and rice grain are reduced [207,210,214,306,307]. Organic forms of arsenic also are taken up by rice, via the silicic acid pathway [207,305].

Li et al. [207] examined the effectiveness of silicon fertilizer in reducing arsenic uptake, in a pot experiment using soil from an arable field on the Rothamsted farm in southeastern England. The authors applied $20 \mathrm{~g}$ of $\mathrm{SiO}_{2}$ silica gel per $\mathrm{kg}$ of soil, to provide a sparingly soluble source of silicon that did not affect soil $\mathrm{pH}$. The silicon treatment increased grain yield significantly, while reducing the concentrations of arsenic in the straw and husk by $78 \%$ and $50 \%$, respectively. The concentration of arsenic in rice grain was reduced by $16 \%$. Pati et al. [308] obtained higher grain and straw yields when applying diatomaceous earth $\left(63.7 \% \mathrm{SiO}_{2}\right)$ in a two-year field experiment during the kharif season in West Bengal. The average grain yield obtained with standard fertilizer practices (N,P,K, zinc sulfate, and farmyard manure) was $4687 \mathrm{~kg}$ per ha. The average yields obtained on the treatments that also included diatomaceous earth (DE) were $4863 \mathrm{~kg}$ per ha (DE at $150 \mathrm{~kg}$ per ha), $4907 \mathrm{~kg}$ per ha (DE at $300 \mathrm{~kg}$ per ha), and $5219 \mathrm{~kg}$ per ha (DE at $600 \mathrm{~kg}$ per ha). The authors did not assess arsenic uptake or the economic implications of applying the selected levels of diatomaceous earth [308]. 
The agronomic gains of applying silicon to rice soils have been known for some time. Researchers in Japan began studying the role of silicon in rice production in 1917. They determined that rice leaves infected with blast disease had less silicon content than healthy leaves [304]. In the 1950s, in an effort to boost national food production, the Ministry of Agriculture, Forestry and Fisheries of Japan began promoting the use of slag from the iron industry as a fertilizer for rice fields, following successful trials at experiment stations across the country. The slag contains substantial silicon, largely in the form of calcium silicate, and is free of toxic components [304]. Thus, farmers utilizing slag as a fertilizer gain the benefit of higher yields, while also reducing the likelihood of arsenic uptake in rice grain.

In areas with high concentrations of arsenic in soils and groundwater, silicon amendments also can reduce the negative impacts of arsenic on rice plant performance. Sanglard et al. [309] report that in addition to reducing the uptake of arsenic by rice plants, silicon nutrition can offset to some degree the impairment to photosynthesis caused by arsenic accumulation. Sanglard et al. [310] also showed that silicon can reverse the carbon fixation impairments of arsenic in rice, which occur at the stomatal and mesophyll levels. Thus, silicon amendments to soil can provide multiple benefits in some settings, by reducing arsenic uptake, enhancing rice plant performance, and providing other biotic and abiotic benefits, such as enhanced resistance to the striped stem borer [311] and brown planthoppers [92].

Meharg and Meharg [214] propose two strategies for enhancing and sustaining silicon levels in soils: rice genetics and silicon fertilization. The authors describe initial efforts to improve understanding of the genetic variation in silicon content across rice cultivars, while calling for additional research to identify rice germplasm with high shoot silicon and demonstrating enhanced efficiency of assimilating silicon from soils. The most common forms of silicon fertilizers are industrial byproducts, including the slag from steel mills and blast furnaces [312]. Several naturally occurring minerals are available, such as wollastonite, olivine, and diatomaceous earth, but the cost of mining and transport can exceed the incremental value of use in agriculture [312]. A more affordable option might involve the composting of rice straw, for application to rice paddy fields [214]. However, the process is time consuming, requires space, and has fallen out of favor in countries, such as Japan, where the availability of farm labor has been declining, over time [304]. Research is needed to determine methods for accelerating the composting of rice straw, and for utilizing biochar derived from rice straw as soil amendments [214,313]. Incorporating the ash of rice straw and husks into paddy soils also can enhance silicon availability, thus improving rice plant performance, while not increasing methane emissions [204,314,315].

\section{Conclusions}

Climate change will impact rice production across a large portion of Asia. In some areas, crop yields will increase in some seasons, perhaps in response to higher rainfall at opportune times during the production cycle or with a reduction in cool, summer days in northern regions. In other areas, yields might be reduced due to higher night temperatures, untimely drought conditions, or submergence caused by large storm events. Improvements in water management will be helpful in adapting to climate change, particularly in areas where higher temperatures are likely and where shifts in rainfall patterns are expected. Switching from continuously flooded paddy rice production to intermittent irrigation will reduce irrigation demands in the dry season, when water might become more scarce with climate change. Many farmers also might need to modify their annual production programs to include just one crop of rice during the wet season, while switching to alternative crops in the second and third seasons. In any event, water management will be a key feature of production decisions aimed at adapting to the likely impacts of climate change.

Improvements in water management also will be helpful in reducing methane emissions and arsenic uptake in rice fields. Paddy rice production generates substantial amounts of methane annually, thus adding notably to the amount of greenhouse gases released into the atmosphere each year. Switching from flooded paddy production to aerobic rice production or to alternative crops that are produced in aerobic conditions can substantially reduce regional methane emissions. Nitrous 
oxide emissions can increase when switching from anaerobic to aerobic production, yet the change in production methods generally will reduce global warming potential.

Adopting some form of aerobic rice production also will reduce the release of arsenic from soils to groundwater, and the subsequent uptake of arsenic by rice plants. Arsenic accumulation in rice grain declines sharply when farmers switch from anaerobic to aerobic production methods. Millions of residents of South and Southeast Asia already are exposed to harmful concentrations of arsenic in drinking water. In those areas, and elsewhere, successful efforts to reduce arsenic uptake in rice will be helpful in reducing total exposure, to the benefit of many adults and children who currently consume harmful amounts of arsenic each day.

In paddy rice production areas with monsoonal climates, farmers likely will continue producing at least one crop of rice per year, given that rice production is well-suited to the monsoonal rainfall pattern. The crop calendar for rice might shift, in response to climate change, with implications for crop choices in the second and third seasons. Those choices will be influenced also by the availability of irrigation water in the dry season, expectations regarding the length of the wet and dry seasons, and the farm-level economics of crop production alternatives. Farmers also must consider the risks inherent in their crop production choices, and how those risks will be modified by climate change.

Farmers in many areas of Asia already are implementing adaptation strategies that have been formed, in part, by their long experience with shifting weather patterns and through efforts to increase rice yields. Regional and national investments in irrigation and drainage infrastructure, in plant breeding, and in efforts to transfer knowledge from research settings to the field will be helpful in achieving greater success with farm-level adaptation efforts. Farmers will benefit also from programs that provide timely projections of changes in weather and in the onset and termination of monsoon seasons. Rice production likely will remain the dominant agricultural activity and the primary source of livelihood for millions of smallholders in Asia for many years. Successful adaptation to climate change, in conjunction with substantial reductions in methane generation and arsenic uptake in rice fields will enhance livelihoods and improve public health across much of Asia.

Acknowledgments: I greatly appreciate the helpful comments of two anonymous reviewers.

Conflicts of Interest: The author declares no conflict of interest.

\section{References}

1. Seck, P.A.; Tollens, E.; Wopereis, M.C.S.; Diagne, A.; Bamba, I. Rising trends and variability of rice prices: Threats and opportunities for sub-Saharan Africa. Food Policy 2010, 35, 403-411. [CrossRef]

2. Liersch, S.; Cools, J.; Kone, B.; Koch, H.; Diallo, M.; Reinhardt, J.; Fournet, S.; Aich, V.; Hattermann, F.F. Vulnerability of rice production in the Inner Niger Delta to water resources management under climate variability and change. Environ. Sci. Policy 2013, 34, 18-33. [CrossRef]

3. Muthayya, S.; Sugimoto, J.D.; Montgomery, S.; Maberly, G.F. An overview of global rice production, supply, trade, and consumption. Ann. N. Y. Acad. Sci. 2014, 1324, 7-14. [CrossRef] [PubMed]

4. Rodenburg, J.; Zwart, S.J.; Kiepe, P.; Narteh, L.T.; Dogbe, W.; Wopereis, M.C.S. Sustainable rice production in African inland valleys: Seizing regional potentials through local approaches. Agric. Syst. 2014, 123, 1-11. [CrossRef]

5. Adjao, R.T.; Staatz, J.M. Asian rice economy changes and implications for sub-Saharan Africa. Glob. Food Secur. 2015, 5, 50-55. [CrossRef]

6. Masutomi, Y.; Takahashi, K.; Harasawa, H.; Matsuoka, Y. Impact assessment of climate change on rice production in Asia in comprehensive consideration of process/parameter uncertainty in general circulation models. Agric. Ecosyst. Environ. 2009, 131, 281-291. [CrossRef]

7. Li, T.; Angeles, O.; Radanielson, A.; Marcaida, M.; Manalo, E. Drought stress impacts of climate change on rainfed rice in South Asia. Clim. Chang. 2015, 133, 709-720. [CrossRef]

8. Tripathi, A.; Tripathi, D.K.; Chauhan, D.K.; Kumar, N.; Singh, G.S. Paradigms of climate change impacts on some major food sources of the world: A review on current knowledge and future prospects. Agric. Ecosyst. Environ. 2016, 216, 356-373. [CrossRef] 
9. Adhikari, U.; Nejadhashemi, A.P.; Woznicki, S.A. Climate change and eastern Africa: A review of impact on major crops. Food Energy Secur. 2015, 4, 110-132. [CrossRef]

10. Wassmann, R.; Jagadish, S.V.K.; Sumfleth, K.; Pathak, H.; Howell, G.; Ismail, A.; Serraj, R.; Redona, E.; Singh, R.K.; Heuer, S. Regional vulnerability of climate change impacts on Asian rice production and scope for adaptation. Adv. Agron. 2009, 102, 91-133.

11. Manzanilla, D.O.; Paris, T.R.; Vergara, G.V.; Ismail, A.M.; Pandey, S.; Labios, R.V.; Tatlonghari, G.T.; Acda, R.D.; Chi, T.T.N.; Duoangsila, K.; et al. Submergence risks and farmers' preferences: Implications for breeding sub1 rice in Southeast Asia. Agric. Syst. 2011, 104, 335-347. [CrossRef]

12. Manzanilla, D.O.; Paris, T.R.; Tatlonghari, G.T.; Tobias, A.M.; Chi, T.T.N.; Phuong, N.T.; Siliphouthone, I.; Chamarerk, V.; Bhekasut, P.; Gandasoemita, R. Social and gender perspectives in rice breeding for submergence tolerance in Southeast Asia. Exp. Agric. 2014, 50, 191-215. [CrossRef]

13. Mackill, D.J.; Ismail, A.M.; Singh, U.S.; Labios, R.V.; Paris, T.R. Development and rapid adoption of submergence-tolerant (Sub1) rice varieties. Adv. Agron. 2012, 115, 299-352.

14. Ismail, A.M.; Singh, U.S.; Singh, S.; Dar, M.H.; Mackill, D.J. The contribution of submergence-tolerant (Sub1) rice varieties to food security in flood-prone rainfed lowland areas in Asia. Field Crops Res. 2013, 152, 83-93. [CrossRef]

15. Mottaleb, K.A.; Gumma, M.K.; Mishra, A.K.; Mohanty, S. Quantifying production losses due to drought and submergence of rainfed rice at the household level using remotely sensed MODIS data. Agric. Syst. 2015, 137, 227-235. [CrossRef]

16. Kamoshita, A.; Ouk, M. Field level damage of deepwater rice by the 2011 Southeast Asian Flood in a flood plain of Tonle Sap Lake, Northwest Cambodia. Paddy Water Environ. 2015, 13, 455-463. [CrossRef]

17. Wassmann, R.; Hien, N.X.; Hoanh, C.T.; Tuong, T.P. Sea level rise affecting the Vietnamese Mekong Delta: Water elevation in the flood season and implications for rice production. Clim. Chang. 2004, 66, 89-107. [CrossRef]

18. Mirza, M.M.Q. Climate change, flooding in South Asia and implications. Reg. Environ. Chang. 2011, 11 (Suppl. 1), 95-107. [CrossRef]

19. Souvignet, M.; Laux, P.; Freer, J.; Cloke, H.; Thinh, D.Q.; Thuc, T.; Cullmann, J.; Nauditt, A.; Flügel, W.-A.; Kunstmann, H.; et al. Recent climatic trends and linkages to river discharge in Central Vietnam. Hydrol. Processes 2014, 28, 1587-1601. [CrossRef]

20. Cheng, W.; Sakai, H.; Yagi, K.; Hasegawa, T. Interactions of elevated $\left[\mathrm{CO}_{2}\right]$ and night temperature on rice growth and yield. Agric. For. Meteorol. 2009, 149, 51-58. [CrossRef]

21. Krishnan, P.; Ramakrishnan, B.; Reddy, K.R.; Reddy, V.R. High-temperature effects on rice growth, yield, and grain quality. Adv. Agron. 2011, 111, 87-206.

22. Tao, F.L.; Zhang, Z.; Shi, W.J.; Liu, Y.J.; Xiao, D.P.; Zhang, S.; Zhu, Z.; Wang, M.; Liu, F.S. Single rice growth period was prolonged by cultivars shifts, but yield was damaged by climate change during 1981-2009 in China, and late rice was just opposite. Glob. Chang. Biol. 2013, 19, 3200-3209. [CrossRef] [PubMed]

23. Tao, F.L.; Zhang, Z.; Zhang, S.; Rötter, R.P. Variability in crop yields associated with climate anomalies in China over the past three decades. Reg. Environ. Chang. 2016. [CrossRef]

24. Bai, H.; Tao, F.; Xiao, D.; Liu, F.; Zhang, H. Attribution of yield change for rice-wheat rotation system in China to climate change, cultivars and agronomic management in the past three decades. Clim. Chang. 2016, 135, 539-553. [CrossRef]

25. Ruhul Amin, M.; Zhang, J.; Yang, M. Effects of climate change on the yield and cropping area of major food crops: A case of Bangladesh. Sustainability (Switzerland) 2015, 7, 898-915. [CrossRef]

26. Peng, S.; Huang, J.; Sheehy, J.E.; Laza, R.C.; Visperas, R.M.; Zhong, X.; Centeno, G.S.; Khush, G.S.; Cassman, K.G. Rice yields decline with higher night temperature from global warming. Proc. Natl. Acad. Sci. USA 2004, 101, 9971-9975. [CrossRef] [PubMed]

27. Watanabe, T.; Kume, T. A general adaptation strategy for climate change impacts on paddy cultivation: Special reference to the Japanese context. Paddy Water Environ. 2009, 7, 313-320. [CrossRef]

28. Cho, J.; Oki, T. Application of temperature, water stress, $\mathrm{CO}_{2}$ in rice growth models. Rice 2012, 5, 1-8. [CrossRef]

29. Matthews, R.B.; Kropff, M.J.; Horie, T.; Bachelet, D. Simulating the impact of climate change on rice production in Asia and evaluating options for adaptation. Agric. Syst. 1997, 54, 399-425. [CrossRef] 
30. Krishnan, P.; Swain, D.K.; Chandra Bhaskar, B.; Nayak, S.K.; Dash, R.N. Impact of elevated $\mathrm{CO}_{2}$ and temperature on rice yield and methods of adaptation as evaluated by crop simulation studies. Agric. Ecosyst. Environ. 2007, 122, 232-242. [CrossRef]

31. Ziska, L.H.; Bunce, J.A. Predicting the impact of changing $\mathrm{CO}_{2}$ on crop yields: Some thoughts on food. New Phytol. 2007, 175, 607-618. [CrossRef] [PubMed]

32. Babel, M.S.; Agarwal, A.; Swain, D.K.; Herath, S. Evaluation of climate change impacts and adaptation measures for rice cultivation in Northeast Thailand. Clim. Res. 2011, 46, 137-146. [CrossRef]

33. Hatfield, J.L.; Boote, K.J.; Kimball, B.A.; Ziska, L.H.; Izaurralde, R.C.; Ort, D.; Thomson, A.M.; Wolfe, D. Climate impacts on agriculture: Implications for crop production. Agron. J. 2011, 103, 351-370. [CrossRef]

34. Matsui, T.; Namuco, O.S.; Ziska, L.H.; Horie, T. Effect of high temperature and $\mathrm{CO}_{2}$ concentration on spikelet sterility in indica rice. Field Crops Res. 1997, 51, 213-219. [CrossRef]

35. Baker, J.T.; Allen, L.H.; Boote, K.J. Response of rice to carbon dioxide and temperature. Agric. For. Meteorol. 1992, 60, 153-166. [CrossRef]

36. Cai, C.; Yin, X.; He, S.; Jiang, W.; Si, C.; Struik, P.C.; Luo, W.; Li, G.; Xie, Y.; Xiong, Y.; et al. Responses of wheat and rice to factorial combinations of ambient and elevated $\mathrm{CO}_{2}$ and temperature in FACE experiments. Glob. Chang. Biol. 2016, 22, 856-874. [CrossRef] [PubMed]

37. Wang, J.; Liu, X.; Zhang, X.; Smith, P.; Li, L.; Filley, T.R.; Cheng, K.; Shen, M.; He, Y.; Pan, G. Size and variability of crop productivity both impacted by $\mathrm{CO}_{2}$ enrichment and warming: A case study of 4 year field experiment in a Chinese paddy. Agric. Ecosyst. Environ. 2016, 221, 40-49. [CrossRef]

38. Shah, F.; Huang, J.; Cui, K.; Nie, L.; Shah, T.; Chen, C.; Wang, K. Impact of high-temperature stress on rice plant and its traits related to tolerance. J. Agric. Sci. 2011, 149, 545-556. [CrossRef]

39. Shah, F.; Nie, L.; Cui, K.; Shah, T.; Wu, W.; Chen, C.; Zhu, L.; Ali, F.; Fahad, S.; Huang, J. Rice grain yield and component responses to near $2{ }^{\circ} \mathrm{C}$ of warming. Field Crops Res. 2014, 157, 98-110. [CrossRef]

40. Wassmann, R.; Jagadish, S.V.K.; Heuer, S.; Ismail, A.; Redona, E.; Serraj, R.; Singh, R.K.; Howell, G.; Pathak, H.; Sumfleth, K. Climate change affecting rice production: The physiological and agronomic basis for possible adaptation strategies. Adv. Agron. 2009, 101, 59-122.

41. Mohammed, A.R.; Tarpley, L. Effects of high night temperature and spikelet position on yield-related parameters of rice (Oryza sativa L.) plants. Eur. J. Agron. 2010, 33, 117-123. [CrossRef]

42. Rehmani, M.I.A.; Wei, G.; Hussain, N.; Ding, C.; Li, G.; Liu, Z.; Wang, S.; Ding, Y. Yield and quality responses of two indica rice hybrids to post-anthesis asymmetric day and night open-field warming in lower reaches of Yangtze River delta. Field Crops Res. 2014, 156, 231-241. [CrossRef]

43. Zhao, X.; Fitzgerald, M. Climate change: Implications for the yield of edible rice. PLoS ONE 2013, 8, 1-9. [CrossRef] [PubMed]

44. Zhou, L.; Liang, S.; Ponce, K.; Marundon, S.; Ye, G.; Zhao, X. Factors affecting head rice yield and chalkiness in indica rice. Field Crops Res. 2015, 172, 1-10. [CrossRef]

45. Okada, M.; Iizumi, T.; Hayashi, Y.; Yokozawa, M. Modeling the multiple effects of temperature and radiation on rice quality. Environ. Res. Lett. 2011, 6, 1-8. [CrossRef]

46. Dong, W.; Chen, J.; Wang, L.; Tian, Y.; Zhang, B.; Lai, Y.; Meng, Y.; Qian, C.; Guo, J. Impacts of nighttime post-anthesis warming on rice productivity and grain quality in East China. Crop J. 2014, 2, 63-69. [CrossRef]

47. Weng, J.; Chen, C. Differences between Indica and Japonica rice varieties in $\mathrm{CO}_{2}$ exchange rates in response to leaf nitrogen and temperature. Photosynth. Res. 1987, 14, 171-178. [CrossRef] [PubMed]

48. Peraudeau, S.; Roques, S.; Quiñones, C.O.; Fabre, D.; Van Rie, J.; Ouwerkerk, P.B.F.; Jagadish, K.S.V.; Dingkuhn, M.; Lafarge, T. Increase in night temperature in rice enhances respiration rate without significant impact on biomass accumulation. Field Crops Res. 2015, 171, 67-78. [CrossRef]

49. Welch, J.R.; Vincent, J.R.; Auffhammer, M.; Moya, P.F.; Dobermann, A.; Dawe, D. Rice yields in tropical/subtropical Asia exhibit large but opposing sensitivities to minimum and maximum temperatures. Proc. Natl. Acad. Sci. USA 2010, 107, 14562-14567. [CrossRef] [PubMed]

50. Mainuddin, M.; Kirby, M.; Hoanh, C.T. Adaptation to climate change for food security in the lower Mekong Basin. Food Secur. 2011, 3, 433-450. [CrossRef]

51. Mainuddin, M.; Kirby, M.; Hoanh, C.T. Impact of climate change on rainfed rice and options for adaptation in the lower Mekong Basin. Nat. Hazards 2013, 66, 905-938. [CrossRef]

52. Döll, P. Impact of climate change and variability on irrigation requirements: A global perspective. Clim. Chang. 2002, 54, 269-293. [CrossRef] 
53. Elgaali, E.; Garcia, L.A.; Ojima, D.S. High resolution modeling of the regional impacts of climate change on irrigation water demand. Clim. Chang. 2007, 84, 441-461. [CrossRef]

54. Rehana, S.; Mujumdar, P.P. Regional impacts of climate change on irrigation water demands. Hydrol. Process. 2013, 27, 2918-2933. [CrossRef]

55. Shahid, S. Impact of climate change on irrigation water demand of dry season Boro rice in northwest Bangladesh. Clim. Chang. 2011, 105, 433-453. [CrossRef]

56. Mainuddin, M.; Kirby, M. National food security in Bangladesh to 2050. Food Secur. 2015, 7, $633-646$. [CrossRef]

57. Mainuddin, M.; Kirby, M.; Chowdhury, R.A.R.; Shah-Newaz, S.M. Spatial and temporal variations of, and the impact of climate change on, the dry season crop irrigation requirements in Bangladesh. Irrig. Sci. 2015, 33, 107-120. [CrossRef]

58. Kirby, J.M.; Ahmad, M.D.; Mainuddin, M.; Palash, W.; Quadir, M.E.; Shah-Newaz, S.M.; Hossain, M.M. The impact of irrigation development on regional groundwater resources in Bangladesh. Agric. Water Manag. 2015, 159, 264-276. [CrossRef]

59. Kirby, J.M.; Mainuddin, M.; Mpelasoka, F.; Ahmad, M.D.; Palash, W.; Quadir, M.E.; Shah-Newaz, S.M.; Hossain, M.M. The impact of climate change on regional water balances in Bangladesh. Clim. Chang. 2016, 135, 481-491. [CrossRef]

60. Qureshi, A.S.; Ahmad, Z.U.; Krupnik, T.J. Moving from resource development to resource management: Problems, prospects and policy recommendations for sustainable groundwater management in Bangladesh. Water Resour. Manag. 2015, 29, 4269-4283. [CrossRef]

61. De Silva, C.S.; Weatherhead, E.K.; Knox, J.W.; Rodriguez-Diaz, J.A. Predicting the impacts of climate change-A case study of paddy irrigation water requirements in Sri Lanka. Agric. Water Manag. 2007, 93, 19-29. [CrossRef]

62. Herath, S.; Ratnayake, U. Monitoring rainfall trends to predict diverse impacts: A case study from Sri Lanka (1964-1993). Glob. Environ. Chang. 2004, 14, 71-79. [CrossRef]

63. Esham, M.; Garforth, C. Climate change and agricultural adaptation in Sri Lanka: A review. Clim. Dev. 2013, 5, 66-76. [CrossRef]

64. Wickramagamage, P. Spatial and temporal variation of rainfall trends of Sri Lanka. Theor. Appl. Climatol. 2015. [CrossRef]

65. Domroes, M.; Schaefer, D. Trends of recent temperature and rainfall changes in Sri Lanka. In Proceedings of the International Conference on Climate Change and Variability, Tokyo Metropolitan University, Japan, 13-17 September 1999; Mikami, T., Ed.; 2000; pp. 197-202.

66. Chung, S.-O.; Rodríguez-Díaz, J.A.; Weatherhead, E.K.; Knox, J.W. Climate change impacts on water for irrigating paddy rice in South Korea. Irrig. Drain. 2011, 60, 263-273. [CrossRef]

67. Wang, W.; Sun, F.; Luo, Y.; Xu, J. Changes of rice water demand and irrigation water requirement in southeast China under future climate change. Procedia Eng. 2012, 28, 341-345. [CrossRef]

68. Ye, Q.; Yang, X.; Dai, S.; Chen, G.; Li, Y.; Zhang, C. Effects of climate change on suitable rice cropping areas, cropping systems and crop water requirements in southern China. Agric. Water Manag. 2015, 159, 35-44. [CrossRef]

69. Chiang, J.-L.; Liu, T.-M. Impact of climate change on paddy field irrigation in southern Taiwan. Paddy Water Environ. 2013, 11, 311-320. [CrossRef]

70. Kunimitsu, Y.; Iizumi, T.; Yokozawa, M. Is long-term climate change beneficial or harmful for rice total factor productivity in Japan: Evidence from a panel data analysis. Paddy Water Environ. 2013, 12, $213-225$. [CrossRef]

71. Naylor, R.L.; Battisti, D.S.; Vimont, D.J.; Falcon, W.P.; Burke, M.B. Assessing risks of climate variability and climate change for Indonesian rice agriculture. Proc. Natl. Acad. Sci. USA 2007, 104, 7752-7757. [CrossRef] [PubMed]

72. Iizumi, T.; Luo, J.-J.; Challinor, A.J.; Sakurai, G.; Yokozawa, M.; Sakuma, H.; Brown, M.E.; Yamagata, T. Impacts of El Niño Southern Oscillation on the global yields of major crops. Nat. Commun. 2014, 5, 1-7. [CrossRef] [PubMed]

73. Boer, R.; Suharnoto, Y. Climate change and its impact on Indonesia's food crop sector. In Presented at the Sixth Executive Forum on Natural Resource Management, Los Baños, Philippines, 11-13 April 2012; 18 pages. 
74. Delos Reyes, M.L.F.; David, W.P. The effect of El Niño on rice production in the Philippines. Philipp. Agric. Sci. 2009, 92, 170-185.

75. Rabbani, G.; Rahman, A.; Mainuddin, K. Salinity-induced loss and damage to farming households in coastal Bangladesh. Int. J. Glob. Warm. 2013, 5, 400-414. [CrossRef]

76. Saroar, M. Adaptation strategies against salinity-induced vulnerability in coastal Bangladesh. In Handbook of Climate Change Adaptation; Leal Filho, W., Ed.; Springer-Verlag: Berlin, Germany, 2015.

77. Government of Indonesia (GOI). donesia Climate Change Sectoral Roadmap: Synthesis Report (ICSSR); Ministry of National Development Planning, Republic of Indonesia: Jakarta, Indonesia, 2009.

78. Food and Agriculture Organization (FAO). FAOSTAT Agricultural Production Statistics and Country Food Balance Sheets, 2013. Available online: www.faostat3.fao.org (accessed on 18 July 2015).

79. Perdinan, P.; Boer, R.; Kartikasari, K. Linking climate change adaptation options for rice production and sustainable development in Indonesia. J. Agrometeorol. 2008, 22, 94-107.

80. Government of Indonesia (GOI). donesia Second National Communication under the United Nations Framework Convention on Climate Change (UNFCCC); Ministry of Environment, Republic of Indonesia: Jakarta, Indonesia, 2010.

81. Bottrell, D.G.; Schoenly, K.G. Resurrecting the ghost of green revolutions past: The brown planthopper as a recurring threat to high-yielding rice production in tropical Asia. J. Asia-Pac. Entomol. 2012, 15, 122-140. [CrossRef]

82. Savary, S.; Horgan, F.; Willocquet, L.; Heong, K.L. A review of principles for sustainable pest management in rice. Crop Prot. 2012, 32, 54-63. [CrossRef]

83. Ali, M.P.; Huang, D.; Nachman, G.; Ahmed, N.; Begum, M.A.; Rabbi, M.F. Will climate change affect outbreak patterns of planthoppers in Bangladesh? PLoS ONE 2014, 9, 1-10. [CrossRef] [PubMed]

84. Heong, K.L. Corrigendum to "Rice planthopper problems in Asia-Consequences of ecosystem breakdown induced by insecticide misuse" [Crop Prot. 61 (2014)]. Crop Prot. 2014, 65, 247. [CrossRef]

85. Heong, K.L.; Wong, L.; Delos Reyes, J.H. Addressing planthopper threats to Asian rice farming and food security: Fixing insecticide misuse. In Rice Planthoppers: Ecology, Management, Socio Economics and Policy; Heong, K.L., Cheng, J.A., Escalada, M.M., Eds.; Zhejiang University Press: Hangzhou, China; Springer Science+Business Media: Dordrecht, The Netherlands, 2015; pp. 69-80.

86. Yao, F.-L.; You, M.-S.; Vasseur, L.; Yang, G.; Zheng, Y.-K. Polycultural manipulation for better regulation of planthopper populations in irrigated rice-based ecosystems. Crop Prot. 2012, 34, 104-111. [CrossRef]

87. Brar, D.S.; Virk, P.S.; Jena, K.K.; Khush, G.S. Breeding for resistance to planthoppers in rice. In Planthoppers: New Threats to the Sustainability of Intensive Rice Production Systems in Asia; Heong, K.L., Hardy, B., Eds.; International Rice Research Institute: Los Baños, Philippines, 2009; pp. 401-428.

88. Shi, B.-K.; Huang, J.-L.; Hu, C.-X.; Hou, M.-L. Interactive effects of elevated $\mathrm{CO}_{2}$ and temperature on rice planthopper, Nilaparvata lugens. J. Integr. Agric. 2014, 13, 1520-1529. [CrossRef]

89. Huan, N.H.; Thiet, L.V.; Chien, H.V.; Heong, K.L. Farmers' participatory evaluation of reducing pesticides, fertilizers and seed rates in rice farming in the Mekong Delta, Vietnam. Crop Prot. 2005, 24, 457-464. [CrossRef]

90. Huan, N.H.; Chien, H.V.; Quynh, P.V.; Tan, P.S.; Du, P.V.; Escalada, M.M.; Heong, K.L. Motivating rice farmers in the Mekong Delta to modify pest management and related practices through mass media. Int. J. Pest Manag. 2008, 54, 339-346. [CrossRef]

91. Heong, K.L.; Escalada, M.M.; Huan, N.H.; Ky Ba, V.H.; Quynh, P.V.; Thiet, L.V.; Chien, H.V. Entertainment-education and rice pest management: A radio soap opera in Vietnam. Crop Prot. 2008, 27, 1392-1397. [CrossRef]

92. He, W.; Yang, M.; Li, Z.; Qiu, J.; Liu, F.; Qu, X.; Qiu, Y.; Li, R. High levels of silicon provided as a nutrient in hydroponic culture enhances rice plant resistance to brown planthopper. Crop Prot. 2015, 67, $20-25$. [CrossRef]

93. Horgan, F.G.; Ramal, A.F.; Bentur, J.S.; Kumar, R.; Bhanu, K.V.; Sarao, P.S.; Iswanto, E.H.; Chien, H.V.; Phyu, M.H.; Bernal, C.C.; et al. Virulence of brown planthopper (Nilaparvata lugens) populations from South and South East Asia against resistant rice varieties. Crop Prot. 2015, 78, 222-231. [CrossRef]

94. Chun, J.A.; Li, S.; Wang, Q.; Lee, W.-S.; Lee, E.-J.; Horstmann, N.; Park, H.; Veasna, T.; Vanndy, L.; Pros, K.; et al. Assessing rice productivity and adaptation strategies for Southeast Asia under climate change through multi-scale crop modeling. Agric. Syst. 2016, 143, 14-21. [CrossRef] 
95. Alam, K. Farmers' adaptation to water scarcity in drought-prone environments: A case study of Rajshahi District, Bangladesh. Agric. Water Manag. 2015, 148, 196-206. [CrossRef]

96. Alauddin, M.; Sarker, M.A.R. Climate change and farm-level adaptation decisions and strategies in drought-prone and groundwater-depleted areas of Bangladesh: An empirical investigation. Ecol. Econ. 2014, 106, 204-213. [CrossRef]

97. Okada, M.; Iizumi, T.; Sakurai, G.; Hanasaki, N.; Sakai, T.; Okamoto, K.; Yokozawa, M. Modeling irrigation-based climate change adaptation in agriculture: Model development and evaluation in Northeast China. J. Adv. Model. Earth Syst. 2015, 7, 1409-1424. [CrossRef]

98. Esham, M.; Garforth, C. Agricultural adaptation to climate change: Insights from a farming community in Sri Lanka. Mitig. Adapt. Strateg. Glob. Chang. 2013, 18, 535-549. [CrossRef]

99. Dharmarathna, W.R.S.S.; Herath, S.; Weerakoon, S.B. Changing the planting date as a climate change adaptation strategy for rice production in Kurunegala disrict, Sri Lanka. Sustain. Sci. 2014, 9, 103-111. [CrossRef]

100. Le Dang, H.; Li, E.; Nuberg, I.; Bruwer, J. Farmers' assessments of private adaptive measures to climate change and influential factors: A study in the Mekong Delta, Vietnam. Nat. Hazards 2014, 71, 385-401. [CrossRef]

101. Moniruzzaman, S. Crop choice as climate change adaptation: Evidence from Bangladesh. Ecol. Econ. 2015, 118, 90-98. [CrossRef]

102. Shrestha, S.; Deb, P.; Bui, T.T.T. Adaptation strategies for rice cultivation under climate change in Central Vietnam. Mitig. Adapt. Strateg. Glob. Chang. 2016, 21, 15-37. [CrossRef]

103. Deb, P.; Tran, D.A.; Udmale, P.D. Assessment of the impacts of climate change and brackish irrigation water on rice productivity and evaluation of adaptation measures in Ca Mau province, Vietnam. Theor. Appl. Climatol. 2015, 1-16. [CrossRef]

104. Shrestha, S.; Bui, T.T.T. Assessment of the climate-change impacts and evaluation of adaptation measures for paddy productivity in Quang Nam province, Vietnam. Paddy Water Environ. 2015, 13, 241-253. [CrossRef]

105. Banerjee, S.; Das, S.; Mukherjee, A.; Mukherjee, A.; Saikia, B. Adaptation strategies to combat climate change effect on rice and mustard in Eastern India. Mitig. Adapt. Strateg. Glob. Chang. 2016, 21, 249-261. [CrossRef]

106. Rajwade, Y.A.; Swain, D.K.; Tiwari, K.N.; Mohanty, U.C.; Goswami, P. Evaluation of Field Level Adaptation Measures under the Climate Change Scenarios in Rice Based Cropping System in India. Environ. Process. 2015, 2, 669-687. [CrossRef]

107. Xu, C.-C.; Wu, W.-X.; Ge, Q.-S.; Zhou, Y.; Lin, Y.-M.; Li, Y.-M. Simulating climate change impacts and potential adaptations on rice yields in the Sichuan Basin, China. Mitig. Adapt. Strateg. Glob. Chang. 2015. [CrossRef]

108. Peñalba, L.M.; Elazegui, D.D. Improving adaptive capacity of small-scale rice farmers: Comparative analysis of Lao PDR and the Philippines. World Appl. Sci. J. 2013, 24, 1211-1220.

109. Wood, S.A.; Jina, A.S.; Jain, M.; Kristjanson, P.; DeFries, R.S. Smallholder farmer cropping decisions related to climate variability across multiple regions. Glob. Environ. Chang. 2014, 25, 163-172. [CrossRef]

110. Swe, L.M.M.; Shrestha, R.P.; Ebbers, T.; Jourdain, D. Farmers' perception of and adaptation to climate-change impacts in the Dry Zone of Myanmar. Clim. Dev. 2015, 7, 437-453. [CrossRef]

111. Shankar, R.; Nagasree, K.; Venkateswarlu, B.; Maraty, P. Constraints and suggestions in adopting seasonal climate forecasts by farmers in South India. J. Agric. Educ. Ext. 2011, 17, 153-163. [CrossRef]

112. Guo, M.; Jia, X.; Huang, J.; Kumar, K.B.; Burger, N.E. Farmer field school and farmer knowledge acquisition in rice production: Experimental evaluation in China. Agric. Ecosyst. Environ. 2015, 209, 100-107. [CrossRef]

113. Nidumolu, U.B.; Hayman, P.T.; Hochman, Z.; Horan, H.; Reddy, D.R.; Sreenivas, G.; Kadiyala, D.M. Assessing climate risks in rainfed farming using farmer experience, crop calendars and climate analysis. J. Agric. Sci. 2015, 153, 1380-1393. [CrossRef]

114. Flor, R.J.; Singleton, G.; Casimero, M.; Abidin, Z.; Razak, N.; Maat, H.; Leeuwis, C. Farmers, institutions and technology in agricultural change processes: Outcomes from Adaptive Research on rice production in Sulawesi, Indonesia. Int. J. Agric. Sustain. 2016, 14, 166-186. [CrossRef]

115. Stigter, K.; Winarto, Y.T.; Ofori, E.; Zuma-Netshiukhwi, G.; Nanja, D.; Walker, S. Extension agrometeorology as the answer to stakeholder realities: Response farming and the consequences of climate change. Atmosphere 2013, 4, 237-253. [CrossRef]

116. Stigter, K. Agrometeorology from science to extension: Assessment of needs and provision of services. Agric. Ecosyst. Environ. 2008, 126, 153-157. [CrossRef] 
117. Stigter, K. Coping with climate risk in agriculture needs farmer oriented research and extension policies. Sci. Agricola 2008, 65, 108-115. [CrossRef]

118. Winarto, Y.T.; Stigter, K.; Anantasari, E.; Hidayah, S.N. Climate field schools in Indonesia: Improving "response farming" to climate change. LEISA Mag. 2008, 24, 16-18.

119. Qian, A.C.; Uddin, T.A. Climate change and food security: Building resilience by means of climate field schools. In Debt-for-Development Exchanges History and New Applications; Buckley, R.P., Ed.; Cambridge University Press: Cambridge, UK, 2011.

120. Siregar, P.R.; Crane, T.A. Climate information and agricultural practice in adaptation to climate variability: The case of climate field schools in Indramayu, Indonesia. Cult. Agric. Food Environ. 2011, 33, 55-69. [CrossRef]

121. Stigter, K.; Winarto, Y.T. How to generate and support a rural response to climate change. In Agrometeorological Learning: Coping Better with Climate Change; Winarto, Y.T., Stigter, K., Eds.; LAP LAMBERT Academic Publishing GmbH \& Co. KG: Saarbrucken, Germany, 2011.

122. Lal, M. Implications of climate change in sustained agricultural productivity in South Asia. Reg. Environ. Chang. 2011, 11 (Suppl. 1), 79-94. [CrossRef]

123. Ondrasek, G.; Rengel, Z.; Petosic, D.; Filipovic, V. Land and water management strategies for the improvement of crop production. In Emerging Technologies and Management of Crop Stress Tolerance, Volume 2: A Sustainable Approach; Ahmad, P., Rasool, S., Eds.; Elsevier: Amsterdam, The Netherlands, 2014.

124. Kumar, A.; Sharma, P.; Joshi, S. Assessing the impacts of climate change on land productivity in Indian crop agriculture: An evidence from panel data analysis. J. Agric. Sci. Technol. 2016, 18, 1-13.

125. Jung, Y.; Shin, Y.; Jang, C.H.; Kum, D.; Kim, Y.S.; Lim, K.J.; Kim, H.B.; Park, T.S.; Lee, S.O. Estimation of flood risk index considering the regional flood characteristics: A case of South Korea. Paddy Water Environ. 2014, 12 (Suppl. 1), 41-49. [CrossRef]

126. Tezuka, S.; Takiguchi, H.; Kazama, S.; Sato, A.; Kawagoe, S.; Sarukkalige, R. Estimation of the effects of climate change on flood-triggered economic losses in Japan. Int. J. Disaster Risk Reduct. 2014, 9, 58-67. [CrossRef]

127. Ray, P.A.; Yang, Y.-C.E.; Wi, S.; Khalil, A.; Chatikavanij, V.; Brown, C. Room for improvement: Hydroclimatic challenges to poverty-reducing development of the Brahmaputra River basin. Environ. Sci. Policy 2015, 54, 64-80. [CrossRef]

128. Wenger, C. Better use and management of levees: Reducing flood risk in a changing climate. Environ. Rev. 2015, 23, 240-255. [CrossRef]

129. O'Connell, P.E.; O'Donnell, G. Towards modelling flood protection investment as a coupled human and natural system. Hydrol. Earth Syst. Sci. 2014, 18, 155-171. [CrossRef]

130. Vikram, P.; Mallikarjuna Swamy, B.P.; Dixit, S.; Ahmed, H.U.; Cruz, M.T.S.; Singh, A.K.; Kumar, A. qDTY 1.1 , a major QTL for rice grain yield under reproductive-stage drought stress with a consistent effect in multiple elite genetic backgrounds. BMC Genet. 2011, 12, 1-15. [CrossRef] [PubMed]

131. Dixit, S.; Singh, A.; Kumar, A. Rice breeding for high grain yield under drought: A strategic solution to a complex problem. Int. J. Agron. 2014, 2014, 863683. [CrossRef]

132. Pray, C.; Nagarajan, L.; Li, L.; Huang, J.; Hu, R.; Selvaraj, K.N.; Napasintuwong, O.; Babu, R.C. Potential impact of biotechnology on adaption of agriculture to climate change: The case of drought tolerant rice breeding in Asia. Sustainability 2011, 3, 1723-1741. [CrossRef]

133. Hossain, M.; Jaim, W.M.H.; Alam, M.S.; Rahman, A.N.M.M. Rice Biodiversity in Bangladesh: Adoption, Diffusion and Disappearance of Varieties; BRAC Research and Evaluation Division: Dhaka, Bangladesh, 2013; Available online: http://research.brac.net/publications/rice\%20biodiversity_book.pdf (accessed on 26 December 2015).

134. Porto-Neto, L.R.; Reverter, A.; Prayaga, K.C.; Chan, E.K.F.; Johnston, D.J.; Hawken, R.J.; Fordyce, G.; Garcia, J.F.; Sonstegard, T.S.; Bolormaa, S.; et al. The genetic architecture of climatic adaptation of tropical cattle. PLOS ONE 2014, 9, 1-22.

135. Biscarini, F.; Nicolazzi, E.; Alessandra, S.; Boettcher, P.; Gandini, G. Challenges and opportunities in genetic improvement of local livestock breeds. Front. Genet. 2015, 6, 1-7. [CrossRef] [PubMed]

136. Kantanen, J.; Løvendahl, P.; Strandberg, E.; Eythorsdottir, E.; Li, M.-H.; Kettunen-Praebel, A.; Berg, P.; Meuwissen, T. Utilization of farm animal genetic resources in a changing agroecological environment in the Nordic countries. Front. Genet. 2015, 6, 1-9. [CrossRef] [PubMed] 
137. Prasad, C.S.; Sejian, V. Climate change impact on livestock sector: Visioning 2025. In Climate Change Impact on Livestock: Adaptation and Mitigation; Sejian, V., Gaughan, J., Baumgard, L., Prasad, C., Eds.; Springer: London, UK, 2015; pp. 479-489.

138. Cai, W.; Borlace, S.; Lengaigne, M.; Van Rensch, P.; Collins, M.; Vecchi, G.; Timmermann, A.; Santoso, A.; Mcphaden, M.J.; Wu, L.; et al. Increasing frequency of extreme El Niño events due to greenhouse warming. Nat. Clim. Chang. 2014, 4, 111-116. [CrossRef]

139. Semenov, M.A.; Stratonovitch, P.; Alghabari, F.; Gooding, M.J. Adapting wheat in Europe for climate change. J. Cereal Sci. 2014, 59, 245-256. [CrossRef] [PubMed]

140. Shepherd, T.G. Atmospheric circulation as a source of uncertainty in climate change projections. Nat. Geosci. 2014, 7, 703-708. [CrossRef]

141. Islam, M.R.; Gregorio, G.B. Progress of salinity tolerant rice variety development in Bangladesh. SABRAO J. Breed. Genet. 2013, 45, 21-30.

142. Islam, M.R.; Sarker, M.R.A.; Sharma, N.; Rahman, M.A.; Collard, B.C.Y.; Gregorio, G.B.; Ismail, A.M. Assessment of adaptability of recently released salt tolerant rice varieties in coastal regions of South Bangladesh. Field Crops Res. 2015. in press. [CrossRef]

143. Piman, T.; Lennaerts, T.; Southalack, P. Assessment of hydrological changes in the lower mekong basin from basin-wide development scenarios. Hydrol. Process. 2013, 27, 2115-2125. [CrossRef]

144. Ngo, M.T.; Lee, J.M.; Lee, H.A.; Woo, N.C. The sustainability risk of Ho Chi Minh City, Vietnam, due to saltwater intrusion. Geosci. J. 2014, 19, 547-560. [CrossRef]

145. Renaud, F.G.; Le, T.T.H.; Lindener, C.; Guong, V.T.; Sebesvari, Z. Resilience and shifts in agro-ecosystems facing increasing sea-level rise and salinity intrusion in Ben Tre Province, Mekong Delta. Clim. Chang. 2015, 133, 69-84. [CrossRef]

146. Van Pham, H.; Lee, S.-I. Assessment of seawater intrusion potential from sea-level rise and groundwater extraction in a coastal aquifer. Desalination Water Treat. 2015, 53, 2324-2338. [CrossRef]

147. Collard, B.C.Y.; Septiningsih, E.M.; Das, S.R.; Caradang, J.J.; Pamplona, A.M.; Sanchez, D.L.; Kato, Y.; Ye, G.; Reddy, J.N.; Singh, U.S.; et al. Developing new flood-tolerant varieties at the International Rice Research Institute (IRRI). SABRAO J. Breed. Genet. 2013, 45, 42-56.

148. Singh, U.S.; Dar, M.H.; Singh, S.; Zaidi, N.W.; Bari, M.A.; Mackill, D.J.; Collard, B.C.Y.; Singh, V.N.; Singh, J.P.; Reddy, J.N.; et al. Field performance, dissemination, impact and tracking of submergence tolerant (Sub1) rice varieties in South Asia. SABRAO J. Breed. Genet. 2013, 45, 112-131.

149. Sarangi, S.K.; Maji, B.; Singh, S.; Sharma, D.K.; Burman, D.; Mandal, S.; Singh, U.S.; Ismail, A.M.; Haefele, S.M. Using improved variety and management enhances rice productivity in stagnant flood-affected tropical coastal zones. Field Crops Res. 2015. in press. [CrossRef]

150. Korinsak, S.; Siangliw, M.; Kotcharerk, J.; Jairin, J.; Siangliw, J.L.; Jongdee, B.; Pantuwan, G.; Sidthiwong, N.; Toojinda, T. Improvement of the submergence tolerance and the brown planthopper resistance of the Thai jasmine rice cultivar KDML105 by pyramiding Sub1 and Qbph12. Field Crops Res. 2016, 188, 105-112. [CrossRef]

151. Kawanishi, M.; Mimura, N. Assessment of insurance for paddy production: A case study in Indonesia. Clim. Dev. 2015, 7, 257-266. [CrossRef]

152. Iizumi, T.; Yokozawa, M.; Hayashi, Y.; Kimura, F. Climate change impact on rice insurance payouts in Japan. J. Appl. Meteorol. Climatol. 2008, 47, 2265-2278. [CrossRef]

153. Schütz, H.; Seiler, W.; Conrad, R. Processes involved in formation and emission of methane in rice paddies. Biogeochemistry 1989, 7, 33-53. [CrossRef]

154. Barron, W.; Hills, P. Concerns over biomass sources of greenhouse gases: Potential issues in selected Asian nations. Int. J. Environ. Stud. 1991, 38, 181-188. [CrossRef]

155. Wassmann, R.; Papen, H.; Rennenberg, H. Methane emission from rice paddies and possible mitigation strategies. Chemosphere 1993, 26, 201-217. [CrossRef]

156. Wassmann, R.; Lantin, R.S.; Neue, H.U.; Buendia, L.V.; Corton, T.M.; Lu, Y. Characterization of methane emissions from rice fields in Asia. III. Mitigation options and future research needs. Nutr. Cycl. Agroecosyst. 2000, 58, 23-36. [CrossRef]

157. Duxbury, J.M. The significance of agricultural sources of greenhouse gases. Fertil. Res. 1994, 38, 151-163. [CrossRef]

158. Minami, K. Methane from rice production. Fertil. Res. 1994, 37, 167-179. [CrossRef] 
159. Cao, M.; Gregson, K.; Marshall, S.; Dent, J.B.; Heal, O.W. Global methane emissions from rice paddies. Chemosphere 1996, 33, 879-897. [CrossRef]

160. Cao, M.; Gregson, K.; Marshall, S. Global methane emission from wetlands and its sensitivity to climate change. Atmos. Environ. 1998, 32, 3293-3299. [CrossRef]

161. Jain, N.; Arora, P.; Tomer, R.; Mishra, S.V.; Bhatia, A.; Pathak, H.; Chakraborty, D.; Kumar, V.; Dubey, D.S.; Harit, R.C.; et al. Greenhouse gases emission from soils under major crops in Northwest India. Sci. Total Environ. 2015, 542, 551-561. [CrossRef] [PubMed]

162. Minami, K.; Neue, H.-U. Rice paddies as a methane source. Clim. Chang. 1994, 27, 13-26. [CrossRef]

163. Xiong, Z.; Liu, Y.; Wu, Z.; Zhang, X.; Liu, P.; Huang, T. Differences in net global warming potential and greenhouse gas intensity between major rice-based cropping systems in China. Sci. Rep. 2015, 5, 1-9. [CrossRef] [PubMed]

164. Wang, J.; Zhang, X.; Xiong, Z.; Khalil, M.A.; Zhao, X.; Xie, Y.; Xing, G. Methane emissions from a rice agroecosystem in South China: Effects of water regime, straw incorporation and nitrogen fertilizer. Nutr. Cycl. Agroecosyst. 2012, 93, 103-112. [CrossRef]

165. Adhya, T.K.; Linquist, B.; Searchinger, T.; Wassman, R.; Yan, X. Wetting and Drying: Reducing Greenhouse Gas Emissions and Saving Water from Rice Production. Working Paper, Installment 8 of Creating a Sustainable Food Future; World Resources Institute: Washington, DC, USA, 2014; Available online: http://www.worldresourcesreport.org (accessed on 24 February 2016).

166. Finn, D.; Dalal, R.; Klieve, A. Methane in Australian agriculture: Current emissions, sources and sinks, and potential mitigation strategies. Crop Pasture Sci. 2015, 66, 1-22. [CrossRef]

167. Hussain, S.; Peng, S.; Fahad, S.; Khaliq, A.; Huang, J.; Cui, K.; Nie, L. Rice management interventions to mitigate greenhouse gas emissions: A review. Environ. Sci. Pollut. Res. 2015, 22, 3342-3360. [CrossRef] [PubMed]

168. Linquist, B.A.; van Groenigen, K.J.; Adviento-Borbe, M.A.; Pittelkow, C.; van Kessel, C. An agronomic assessment of greenhouse gas emissions from major cereal crops. Glob. Chang. Biol. 2012, 18, 194-209. [CrossRef]

169. An, N.; Fan, M.; Zhang, F.; Christie, P.; Yang, J.; Huang, J.; Guo, S.; Shi, X.; Tang, Q.; Peng, J.; et al. Exploiting co-benefits of increased rice production and reduced greenhouse gas emission through optimized crop and soil management. PLoS ONE 2015, 10, 1-17. [CrossRef] [PubMed]

170. Van Groenigen, K.J.; Osenberg, C.W.; Hungate, B.A. Increased soil emissions of potent greenhouse gases under increased atmospheric $\mathrm{CO}_{2}$. Nature 2011, 475, 214-216. [CrossRef] [PubMed]

171. Van Groenigen, K.J.; van Kessel, C.; Hungate, B.A. Increased greenhouse-gas intensity of rice production under future atmospheric conditions. Nat. Clim. Chang. 2013, 3, 288-291. [CrossRef]

172. Sanchis, E.; Ferrer, M.; Torres, A.G.; Cambra-López, M.; Calvet, S. Effect of water and straw management practices on methane emissions from rice fields: A review through a meta-analysis. Environ. Eng. Sci. 2012, 29, 1053-1062. [CrossRef]

173. Zhang, G.; Ji, Y.; Ma, J.; Xu, H.; Cai, Z.; Yagi, K. Intermittent irrigation changes production, oxidation, and emission of $\mathrm{CH} 4$ in paddy fields determined with stable carbon isotope technique. Soil Biol. Biochem. 2012, 52, 108-116. [CrossRef]

174. Kudo, Y.; Noborio, K.; Shimoozono, N.; Kurihara, R. The effective water management practice for mitigating greenhouse gas emissions and maintaining rice yield in central Japan. Agric. Ecosyst. Environ. 2014, 186, 77-85. [CrossRef]

175. Maris, S.C.; Teira-Esmatges, M.R.; Català, M.M. Influence of irrigation frequency on greenhouse gases emission from a paddy soil. Paddy Water Environ. 2016, 14, 199-210. [CrossRef]

176. Lagomarsino, A.; Agnelli, A.E.; Pastorelli, R.; Pallara, G.; Rasse, D.P.; Silvennoinen, H. Past water management affected GHG production and microbial community pattern in Italian rice paddy soils. Soil Biol. Biochem. 2016, 93, 17-27. [CrossRef]

177. Leon, A.; Kohyama, K.; Yagi, K.; Takata, Y.; Obara, H. The effects of current water management practices on methane emissions in Japanese rice cultivation. Mitig. Adapt. Strateg. Glob. Chang. 2015. [CrossRef]

178. Kanno, T.; Miura, Y.; Tsuruta, H.; Minami, K. Methane emission from rice paddy fields in all of Japanese prefecture: Relationship between emission rates and soil characteristics and organic matter application. Nutr. Cycl. Agroecosyst. 1997, 49, 147-151. [CrossRef] 
179. Ogino, Y.; Ota, S. The evolution of Japan's rice field drainage and development of technology. Irrig. Drain. 2007, 56, S69-S80. [CrossRef]

180. Itoh, M.; Sudo, S.; Mori, S.; Saito, H.; Yoshida, T.; Shiratori, Y.; Suga, S.; Yoshikawa, N.; Suzue, Y.; Mizukami, H.; et al. Mitigation of methane emissions from paddy fields by prolonging midseason drainage. Agric. Ecosyst. Environ. 2011, 141, 359-372. [CrossRef]

181. Yagi, K.; Tsuruta, H.; Kanda, K.; Minami, K. Effect of water management on methane emission from a Japanese rice paddy field: Automated methane monitoring. Glob. Biogeochem. Cycles 1996, 10, 255-267. [CrossRef]

182. Tyagi, L.; Kumari, B.; Singh, S.N. Water management: A tool for methane mitigation from irrigated paddy fields. Sci. Total Environ. 2010, 408, 1085-1090. [CrossRef] [PubMed]

183. Shiratori, Y.; Watanabe, H.; Furukawa, Y.; Tsuruta, H.; Inubushi, K. Effectiveness of a subsurface drainage system in poorly drained paddy fields on reduction of methane emissions. Soil Sci. Plant Nutr. 2007, 53, 387-400. [CrossRef]

184. Furukawa, Y.; Shiratori, Y.; Inubushi, K. Depression of methane production potential in paddy soils by subsurface drainage systems. Soil Sci. Plant Nutr. 2008, 54, 950-959. [CrossRef]

185. Li, C.; Qiu, J.; Frolking, S.; Xiao, X.; Salas, W.; Moore, B., III; Boles, S.; Huang, Y.; Sass, R. Reduced methane emissions from large-scale changes in water management of China's rice paddies during 1980-2000. Geophys. Res. Lett. 2002, 29, 33-1-33-4. [CrossRef]

186. Kreye, C.; Dittert, K.; Zheng, X.; Zhang, X.; Lin, S.; Tao, H.; Sattelmacher, B. Fluxes of methane and nitrous oxide in water-saving rice production in north China. Nutr. Cycl. Agroecosyst. 2007, 77, 293-304. [CrossRef]

187. Ciais, P.; Sabine, C.; Bala, G.; Bopp, L.; Brovkin, V.; Canadell, J.; Chhabra, A.; DeFries, R.; Galloway, J.; Heimann, M.; et al. Carbon and Other Biogeochemical Cycles. In Climate Change 2013: The Physical Science Basis; Stocker, T.F., Qin, D., Plattner, G.-K., Tignor, M., Allen, S.K., Boschung, J., Nauels, A., Xia, Y., Bex, V., Midgley, P.M., Eds.; Contribution of Working Group I to the Fifth Assessment Report of the Intergovernmental Panel on Climate Change; Cambridge University Press: Cambridge, UK; New York, NY, USA, 2013.

188. Bouman, B.A.M.; Peng, S.; Castaneda, A.R.; Visperas, R.M. Yield and water use of irrigated tropical aerobic rice systems. Agric. Water Manag. 2005, 74, 87-105. [CrossRef]

189. Atlin, G.N.; Lafitte, H.R.; Tao, D.; Laza, M.; Amante, M.; Courtois, B. Developing rice cultivars for high-fertility upland systems in the Asian tropics. Field Crops Res. 2006, 97, 43-52. [CrossRef]

190. Bouman, B.A.M.; Yang, X.; Wang, H.; Wang, Z.; Zhao, J.; Chen, B. Performance of aerobic rice varieties under irrigated conditions in North China. Field Crops Res. 2006, 97, 53-65. [CrossRef]

191. Zhao, D.L.; Atlin, G.N.; Amante, M.; Cruz, M.T.S.; Kumar, A. Developing aerobic rice cultivars for water-short irrigated and drought-prone rainfed areas in the tropics. Crop Sci. 2010, 50, 2268-2276. [CrossRef]

192. Okami, M.; Kato, Y.; Kobayashi, N.; Yamagashi, J. Agronomic performance of an IR64 introgression line with large leaves derived from New Plant Type rice in aerobic culture. Eur. J. Agron. 2014, 58, 11-17. [CrossRef]

193. Xue, C.-Y.; Yang, X.-G.; Bouman, B.A.M.; Deng, W.; Zhang, Q.-P.; Yang, J.; Yan, W.-X.; Zhang, T.-Y.; Rouzi, A.-J.; Wang, H.-Q.; et al. Effects of irrigation and nitrogen on the performance of aerobic rice in nortern China. J. Ingegrative Plant Biol. 2008, 50, 1589-1600. [CrossRef] [PubMed]

194. Tarlera, S.; Capurro, M.C.; Irisarri, P.; Scavino, A.F.; Cantou, G.; Roel, A. Yield-scaled global warming potential of two irrigation management systems in a highly productive rice system. Sci. Agricola 2016, 73, 43-50. [CrossRef]

195. Xu, Y.; Zhan, M.; Cao, C.; Tian, S.; Ge, J.; Li, S.; Wang, M.; Yuan, G. Improved water management to reduce greenhouse gas emissions in no-till rapeseed-rice rotations in Central China. Agric. Ecosyst. Environ. 2016, 221, 87-98. [CrossRef]

196. Pandey, A.; Mai, V.T.; Vu, D.Q.; Bui, T.P.L.; Mai, T.L.A.; Jensen, L.S.; de Neergaard, A. Organic matter and water management strategies to reduce methane and nitrous oxide emissions from rice paddies in Vietnam. Agric. Ecosyst. Environ. 2014, 196, 137-146. [CrossRef]

197. Matthews, R.B.; Wassmann, R.; Buendia, L.V.; Knox, J.W. Using a crop/soil simulation model and GIS techniques to assess methane emissions from rice fields in Asia. II. Model validation and sensitivity analysis. Nutr. Cycl. Agroecosyst. 2000, 58, 161-177. [CrossRef]

198. Le Mer, J.; Roger, P. Production, oxidation, emission and consumption of methane by soils: A review. Eur. J. Soil Biol. 2001, 37, 25-50. [CrossRef] 
199. Bao, Q.-L.; Xiao, K.-Q.; Chen, Z.; Yao, H.-Y.; Zhu, Y.-G. Methane production and methanogenic archaeal communities in two types of paddy soil amended with different amounts of rice straw. FEMS Microbiol. 2014, 88, 372-385. [CrossRef] [PubMed]

200. Sander, B.O.; Samson, M.; Buresh, R.J. Methane and nitrous oxide emissions from floded rice fields as affected by water and straw management between rice crops. Geoderma 2014, 235-236, 355-362. [CrossRef]

201. Ly, P.; Duong Vu, Q.; Jensen, L.S.; Pandey, A.; de Neergaard, A. Effects of rice straw, biochar and mineral fertiliser on methane $\left(\mathrm{CH}_{4}\right)$ and nitrous oxide $\left(\mathrm{N}_{2} \mathrm{O}\right)$ emissions from rice (Oryza sativa L.) grown in a rain-fed lowland rice soil of Cambodia: A pot experiment. Paddy Water Environ. 2014, 13, 465-475. [CrossRef]

202. Pratiwi, E.P.A.; Shinogi, Y. Rice husk biochar application to paddy soil and its effects on soil physical properties, plant growth, and methane emission. Paddy Water Environ. 2016. [CrossRef]

203. Mohammadi, A.; Cowie, A.; Mai, T.L.A.; de la Rosa, R.A.; Kristiansen, P.; Brandão, M.; Joseph, S. Biochar use for climate-change mitigation in rice cropping systems. J. Clean. Prod. 2016, 116, 61-70. [CrossRef]

204. Penido, E.S.; Bennett, A.J.; Hanson, T.E.; Seyfferth, A.L. Biogeochemical impacts of silicon-rich residue incorporation into flooded soils: Implications for rice nutrition and cycling of arsenic. Plant Soil 2016, 399, 75-87. [CrossRef]

205. Savant, N.K.; Datnoff, L.E.; Snyder, G.H. Depletion of plant-available silicon in soils: A possible cause of declining rice yields. Commun. Soil Sci. Plant Anal. 1997, 28, 1245-1252. [CrossRef]

206. Savant, N.K.; Snyder, G.H.; Datnoff, L.E. Silicon management and sustainable rice production. Adv. Agron. 1997, 58, 151-199.

207. Li, R.Y.; Stroud, J.L.; Ma, J.F.; McGrath, S.P.; Zhao, F.J. Mitigation of arsenic accumulation in rice with water management and silicon fertilization. Environ. Sci. Technol. 2009, 43, 3778-3783. [CrossRef] [PubMed]

208. Bogdan, K.; Schenk, M.K. Evaluation of soil characteristics potentially affecting arsenic concentration in paddy rice (Oryza sativa L.). Environ. Pollut. 2012, 157, 2617-2621. [CrossRef] [PubMed]

209. Guntzer, F.; Keller, C.; Meunier, J.-D. Benefits of plant silicon for crops: A review. Agron. Sustain. Dev. 2012, 32, 201-213. [CrossRef]

210. Seyfferth, A.L.; Fendorf, S. Silicate mineral impacts on the uptake and storage of arsenic and plant nutrients in rice (Oryza sativa L.). Environ. Sci. Technol. 2012, 46, 13176-13183. [CrossRef] [PubMed]

211. Zhu, Y.; Gong, H. Beneficial effects of silicon on salt and drought tolerance in plants. Agron. Sustain. Dev. 2014, 34, 455-472. [CrossRef]

212. Adrees, M.; Ali, S.; Rizwan, M.; Zia-ur-Rehman, M.; Ibrahim, M.; Abbas, F.; Farid, M.; Qayyum, M.F.; Irshad, M.K. Mechanisms of silicon-mediated alleviation of heavy metal toxicity in plants: A review. Ecotoxicol. Environ. Saf. 2015, 119, 186-197. [CrossRef] [PubMed]

213. Farooq, M.A.; Dietz, K.-J. Silicon as versatile player in plant and human biology: Overlooked and poorly understood. Front. Plant Sci. 2015, 6, 1-14. [CrossRef] [PubMed]

214. Meharg, C.; Meharg, A.A. Silicon, the silver bullet for mitigating biotic and abiotic stress, and improving grain quality in rice? Environ. Exp. Bot. 2015, 120, 8-17. [CrossRef]

215. Sui, Y.; Gao, J.; Liu, C.; Zhang, W.; Lan, Y.; Li, S.; Meng, J.; Xu, Z.; Tang, L. Interactive effects of straw-derived biochar and $\mathrm{N}$ fertilization on soil $\mathrm{C}$ storage and rice productivity in rice paddies of Northeast China. Sci. Total Environ. 2016, 544, 203-210. [CrossRef] [PubMed]

216. Pode, R. Potential applications of rice husk ash waste from rice husk biomass power plant. Renew. Sustain. Energy Rev. 2016, 53, 1468-1485. [CrossRef]

217. Weller, S.; Janz, B.; Jörg, L.; Kraus, D.; Racela, H.S.U.; Wassmann, R.; Butterbach-Bahl, K.; Kiese, R. Greenhouse gas emissions and global warming potential of traditional and diversified tropical rice rotation systems. Glob. Chang. Biol. 2016, 22, 432-448. [CrossRef] [PubMed]

218. Zhang, Z.-S.; Cao, C.-G.; Guo, L.-J.; Li, C.-F. Emissions of $\mathrm{CH}_{4}$ and $\mathrm{CO}_{2}$ from paddy fields as affected by tillage practices and crop residues in central China. Paddy Water Environ. 2016, 14, 85-92. [CrossRef]

219. Kumar, V.; Ladha, J.K. Direct seeding of rice: Recent developments and future research needs. Adv. Agron. 2011, 111, 297-413.

220. Farooq, M.; Siddique, K.H.M.; Rehman, H.; Aziz, T.; Lee, D.-J.; Wahid, A. Rice direct seeding: Experiences, challenges and opportunities. Soil Tillage Res. 2011, 111, 87-98. [CrossRef]

221. Pathak, H.; Sankhyan, S.; Dubey, D.S.; Bhatia, A.; Jain, N. Dry direct-seeding of rice for mitigating greenhouse gas emission: Field experimentation and simulation. Paddy Water Environ. 2013, 11, 593-601. [CrossRef] 
222. Chauhan, B.S.; Namuco, O.S.; Ocampo, L.A.L.; Son, T.T.N.; Thu, T.T.A.; Nam, N.N.; Phuong, L.N.; Bajwa, A.A. Weedy rice (Oryza sativa f. spontanea) problems and management in wet direct-seeded rice (O. sativa L.) in the Mekong Delta of Vietnam. Crop Prot. 2015, 78, 40-47. [CrossRef]

223. Chauhan, B.S. Weed ecology and weed management strategies for dry-seeded rice in Asia. Weed Technol. 2012, 26, 1-13. [CrossRef]

224. Chauhan, B.S.; Johnson, D.E. Row spacing and weed control timing affect yield of aerobic rice. Field Crops Res. 2011, 121, 226-231. [CrossRef]

225. Matloob, A.; Khaliq, A.; Chauhan, B.S. Weeds of direct-seeded rice in Asia: Problems and opportunities. Adv. Agron. 2015, 130, 291-336.

226. Weerakoon, W.M.W.; Mutunayake, M.M.P.; Bandara, C.; Rao, A.N.; Bhandari, D.C.; Ladha, J.K. Direct-seeded rice culture in Sri Lanka: Lessons from farmers. Field Crops Res. 2011, 121, 53-63. [CrossRef]

227. Gunawardana, D. Harvesting serendipity. Rice Today 2008, 7, 36-39.

228. Mahajan, G.; Chauhan, B.S.; Gill, M.S. Dry-seeded rice culture in Punjab State of India: Lessons learned from farmers. Field Crops Res. 2013, 144, 89-99. [CrossRef]

229. Uphoff, N. Agroecological implications of the System of Rice Intensification (SRI) in Madagascar. Environ. Dev. Sustain. 1999, 1, 297-313. [CrossRef]

230. Uphoff, N.; Kassam, A.; Harwood, R. SRI as a methodology for raising crop and water productivity: Productive adaptations in rice agronomy and irrigation water management. Paddy Water Environ. 2011, 9 , 3-11. [CrossRef]

231. Thakur, A.K.; Uphoff, N.T.; Stoop, W.A. Scientific underpinnings of the system of rice intensification (SRI): What is known so far? Adv. Agron. 2015. in press.

232. Berkhout, E.; Glover, D.; Kuyvenhoven, A. On-farm impact of the System of Rice Intensification (SRI): Evidence and knowledge gaps. Agric. Syst. 2015, 132, 157-166. [CrossRef]

233. Stoop, W.A.; Uphoff, N.; Kassam, A. A review of agricultural research issues raised by the system of rice intensification (SRI) from Madagascar: Opportunities for improving farming systems for resource-poor farmers. Agric. Syst. 2002, 71, 249-274. [CrossRef]

234. Thakur, A.K.; Mohanty, R.K.; Patil, D.U.; Kumar, A. Impact of water management on yield and water productivity with system of rice intensification (SRI) and conventional transplanting in rice. Paddy Water Environ. 2013, 12, 413-424. [CrossRef]

235. Alem, Y.; Eggert, H.; Ruhinduka, R. Improving welfare through climate-friendly agriculture: The case of the system of rice intensification. Environ. Resour. Econ. 2015, 62, 243-263. [CrossRef]

236. Ly, P.; Jensen, L.S.; Bruun, T.B.; de Neergaard, A. Methane $\left(\mathrm{CH}_{4}\right)$ and nitrous oxide $\left(\mathrm{N}_{2} \mathrm{O}\right)$ emissions from the system of rice intensification (SRI) under a rain-fed lowland rice ecosystem in Cambodia. Nutr. Cycl. Agroecosyst. 2013, 97, 13-27. [CrossRef]

237. Jain, N.; Dubey, R.; Dubey, D.S.; Singh, J.; Khanna, M.; Pathak, H.; Bhatia, A. Mitigation of greenhouse gas emission with system of rice intensification in the Indo-Gangetic Plains. Paddy Water Environ. 2014, 12, 355-363. [CrossRef]

238. Suryavanshi, P.; Singh, Y.V.; Prasanna, R.; Bhatia, A.; Shivay, Y.S. Pattern of methane emission and water productivity under different methods of rice crop establishment. Paddy Water Environ. 2013, 11, 321-329. [CrossRef]

239. Mandal, B.K.; Suzuki, K.T. Arsenic round the world: A review. Talanta 2002, 58, 201-235. [CrossRef]

240. Nordstrom, D.K. Worldwide occurrences of arsenic in ground water. Science 2002, 296, 2143-2144. [CrossRef] [PubMed]

241. Hasanuzzaman, M.; Nahar, K.; Hakeem, K.R.; Öztürk, M.; Fujita, M. Arsenic toxicity in plants and possible remediation. In Soil Remediation and Plants: Prospects and Challenges; Hakeem, K., Sabir, M., Öztürk, M., Murmet, A., Eds.; Elsevier: Amsterdam, The Netherlands, 2015.

242. Singh, R.; Sing, S.; Parihar, P.; Singh, V.P.; Prasad, S.M. Arsenic contamination, consequences and remediation techniques: A review. Ecotoxicol. Environ. Saf. 2015, 112, 247-470. [CrossRef] [PubMed]

243. Smith, A.H.; Lopipero, P.A.; Bates, M.N.; Steinmaus, C.M. Arsenic epidemiology and drinking water standards. Science 2002, 296, 2145-2146. [CrossRef] [PubMed]

244. Guha Mazumder, D.N.; Chakraborty, A.K.; Ghose, A.; Gupta, J.D.; Chakraborty, D.P.; Dey, S.B.; Chattopadhyay, N. Chronic arsenic toxicity from drinking tubewell water in rural West Bengal. Bull. World Health Organ. 1988, 66, 499-506. [PubMed] 
245. Ahmed, M.F.; Ahuja, S.; Alauddin, M.; Hug, S.J.; Lloyd, J.R.; Pfaff, A.; Pichler, T.; Saltikov, C.; Stute, M.; van Geen, A. Ensuring safe drinking water in Bangladesh. Science 2006, 314, 1687-1688. [CrossRef] [PubMed]

246. Martinez, V.D.; Vucic, E.A.; Becker-Santos, D.D.; Gil, L.; Lam, W.L. Arsenic exposure and the induction of human cancers. J. Toxicol. 2011, 431287, 1-13. [CrossRef] [PubMed]

247. Hunt, K.M.; Srivastava, R.K.; Elmets, C.A.; Athar, M. The mechanistic basis of arsenicosis: Pathogenesis of skin cancer. Cancer Lett. 2014, 354, 211-219. [CrossRef] [PubMed]

248. Ahmad, S.A.; Khan, M.H. Ground water arsenic contamination and its health effects in Bangladesh. In Handbook of Arsenic Toxicology; Flora, S.J.S., Ed.; Elsevier: Amsterdam, The Netherlands, 2015.

249. Tsuji, J.S.; Garry, M.R.; Perez, V.; Chang, E.T. Low-level arsenic exposure and developmental neurotoxicity in children: A systematic review and risk assessment. Toxicology 2015, 337, 91-107. [CrossRef] [PubMed]

250. Ahsan, H.; Chen, Y.; Parvez, F.; Zablotska, L.; Argos, M.; Hussain, I.; Momotaj, H.; Levy, D.; Cheng, Z.; Slavkovich, V.; et al. Arsenic exposure from drinking water and risk of premalignant skin lesions in Bangladesh: Baseline results from the health effects of arsenic longitudinal study. Am. J. Epidemiol. 2006, 163, 1138-1148. [CrossRef] [PubMed]

251. Meharg, A.A.; Raab, A. Getting to the bottom of arsenic standards and guidelines. Environ. Sci. Technol. 2010, 44, 4395-4399. [CrossRef] [PubMed]

252. Ravenscroft, P.; Brammer, H.; Richards, K. Arsenic Pollution: A Global Synthesis; Wiley-Blackwell: West Sussex, UK, 2009.

253. Fendorf, S.; Michael, H.A.; van Geen, A. Spatial and temporal variations of groundwater arsenic in South and Southeast Asia. Science 2010, 328, 1123-1127. [CrossRef] [PubMed]

254. Flanagan, S.V.; Johnston, R.B.; Zheng, Y. Arsenic in tube well water in Bangladesh: Health and economic impacts and implications for arsenic mitigation. Bull. World Health Organ. 2012, 90, 839-846. [CrossRef] [PubMed]

255. Acharyya, S.K.; Shah, B.A. Groundwater arsenic pollution affecting deltaic West Bengal, India. Curr. Sci. 2010, 99, 1787-1794.

256. Chakraborti, D.; Rahman, M.M.; Das, B.; Murrill, M.; Dey, S.; Mukherjee, S.C.; Dhar, R.K.; Biswas, B.K.; Chowdhury, U.K.; Roy, S.; et al. Status of groundwater arsenic contamination in Bangladesh: A 14-year study report. Water Res. 2010, 44, 5789-5802. [CrossRef] [PubMed]

257. Halder, D.; Bhowmick, S.; Biswas, A.; Chatterjee, D.; Nriagu, J.; Guha Mazumder, D.N.; Šlejkovec, Z.; Jacks, G.; Bhattacharya, P. Risk of arsenic exposure from drinking water and dietary components: Implications for risk management in rural Bengal. Environ. Sci. Technol. 2013, 47, 1120-1127. [CrossRef] [PubMed]

258. Jiang, J.-Q.; Ashekuzzaman, S.M.; Jiang, A.; Sharifuzzaman, S.M.; Chowdhury, S.R. Arsenic contaminated groundwater and its treatment options in Bangladesh. Int. J. Environ. Res. Public Health 2013, 10, 18-46. [CrossRef] [PubMed]

259. Naujokas, M.F.; Anderson, B.; Ahsan, H.; Vasken Aposhian, H.; Graziano, J.H.; Thompson, C.; Suk, W.A. The broad scope of health effects from chronic arsenic exposure: Update on a worldwide public health problem. Environ. Health Perspect. 2013, 121, 295-302. [CrossRef] [PubMed]

260. Benner, S.; Fendorf, S. Arsenic in South Asia groundwater. Geogr. Compass 2010, 4, 1532-1552. [CrossRef]

261. Erban, L.E.; Gorelick, S.M.; Zebker, H.A.; Fendorf, S. Release of arsenic to deep groundwater in the Mekong Delta, Vietnam, linked to pumping-induced land subsidence. Proc. Natl. Acad. Sci. USA 2013, 110, 13751-13756. [CrossRef] [PubMed]

262. Berg, M.; Stengel, C.; Trang, P.T.K.; Hung Viet, P.; Sampson, M.L.; Leng, M.; Samreth, S.; Fredericks, D. Magnitude of arsenic pollution in the Mekong and Red River Deltas-Cambodia and Vietnam. Sci. Total Environ. 2007, 372, 413-425. [CrossRef] [PubMed]

263. Buschmann, J.; Berg, M.; Stengel, C.; Winkel, L.; Sampson, M.; Trang, P.T.K.; Viet, P.H. Contamination of drinking water resources in the Mekong delta floodplains: Arsenic and other trace metals pose serious health risks to population. Environ. Int. 2008, 34, 756-764. [CrossRef] [PubMed]

264. Polya, D.A.; Berg, M.; Gault, A.G.; Takahashi, Y. Arsenic in groundwaters of south-east Asia: With emphasis on Cambodia and Vietnam. Appl. Geochem. 2010, 23, 2968-2976. [CrossRef]

265. Kim, K.-W.; Chanpiwat, P.; Hanh, H.T.; Phan, K.; Sthiannopkao, S. Arsenic geochemistry of groundwater in Southeast Asia. Front. Med. 2011, 5, 420-433. [CrossRef] [PubMed]

266. Agusa, T.; Trang, P.T.K.; Lan, V.M.; Anh, D.H.; Tanabe, S.; Viet, P.H.; Berg, M. Human exposure to arsenic from drinking water in Vietnam. Sci. Total Environ. 2014, 488-489, 562-569. [CrossRef] [PubMed] 
267. Chanpiwat, P.; Himeno, S.; Sthiannopkao, S. Arsenic and other metals' presence in biomarkers of cambodians in arsenic contaminated areas. Int. J. Environ. Res. Public Health 2015, 12, 14285-14300. [CrossRef] [PubMed]

268. Sampson, M.L.; Bostick, B.; Chiew, H.; Hangan, J.M.; Shantz, A. Arsenicosis in Cambodia: Case studies and policy response. Appl. Geochem. 2008, 23, 2976-2985. [CrossRef]

269. Sthiannopkao, S.; Kim, K.W.; Sotham, S.; Choup, S. Arsenic and manganese in tube well waters of Prey Veng and Kandal Provinces, Cambodia. Appl. Geochem. 2008, 23, 1086-1093. [CrossRef]

270. Guha Mazumder, D.N.; Majumdar, K.K.; Santra, S.C.; Kol, H.; Vicheth, C. Occurrence of arsenicosis in a rural village of Cambodia. J. Environ. Sci. Health Part A 2009, 44, 480-487. [CrossRef] [PubMed]

271. Gilbert, P.J.; Polya, D.A.; Cooke, D.A. Arsenic hazard in Cambodian rice from a market-based survey with a case study of Preak Russey village, Kandal Province. Environ. Geochem. Health 2015, 37, 757-766. [CrossRef] [PubMed]

272. Phan, K.; Sthiannopkao, S.; Kim, K.-W.; Wong, M.H.; Sao, V.; Hashim, J.H.; Yasin, M.S.M.; Aljunid, S.M. Health risk assessment of inorganic arsenic intake of Cambodia residents through groundwater drinking pathway. Water Res. 2010, 44, 5777-5788. [CrossRef] [PubMed]

273. Erban, L.E.; Gorelick, S.M.; Fendorf, S. Arsenic in the multi-aquifer system of the Mekong Delta, Vietnam: Analysis of large-scale spatial trends and controlling factors. Environ. Sci. Technol. 2014, 48, 6081-6088. [CrossRef] [PubMed]

274. Williams, P.N.; Villada, A.; Deacon, C.; Raab, A.; Figuerola, J.; Green, A.J.; Feldmann, J.; Meharg, A.A. Greatly enhanced arsenic shoot assimilation in rice leads to elevated grain levels compared to wheat and barley. Environ. Sci. Technol. 2007, 41, 6854-6859. [CrossRef] [PubMed]

275. Meharg, A.A.; Zhao, F.J. Arsenic E Rice; Springer: Dordrecht, The Netherlands, 2012.

276. Su, Y.-H.; McGrath, S.P.; Zhao, F.-J. Rice is more efficient in arsenite uptake and translocation than wheat and barley. Plant Soil 2010, 328, 27-34. [CrossRef]

277. Islam, F.S.; Gault, A.G.; Boothman, C.; Polya, D.A.; Charnock, J.M.; Chatterjee, D.; Lloyd, J.R. Role of metal-reducing bacteria in arsenic release from Bengal delta sediments. Nature 2004, 430, 68-71. [CrossRef] [PubMed]

278. Heikens, A. Arsenic Contamination of Irrigation Water, Soil and Crops in Bangladesh: Risk Implications for Sustainable Agriculture and Food Safety in Asia; Food and Agriculture Organization of the United Nations, Regional Office for Asia and the Pacific: Bangkok, Thailand, 2006.

279. Heikens, A.; Panaullah, G.M.; Meharg, A.A. Arsenic behaviour from groundwater and soil to crops: Impacts on agriculture and food safety. Rev. Eviron. Contam. Toxicol. 2007, 189, 43-87.

280. Harvey, C.F.; Ashfaque, K.N.; Yu, W.; Badruzzaman, A.B.M.; Ali, M.A.; Oates, P.M.; Michael, H.A.; Neumann, R.B.; Beckie, R.; Islam, S.; et al. Groundwater dynamics and arsenic contamination in Bangladesh. Chem. Geol. 2006, 228, 112-136. [CrossRef]

281. Brammer, H. Threat of arsenic to agriculture in India, Bangladesh and Nepal. Econ. Political Wkly. 2008, 43, 79-84.

282. Van Geen, A.; Win, K.H.; Zaw, T.; Naing, W.; Mey, J.L.; Mailloux, B. Confirmation of elevated arsenic levels in groundwater of Myanmar. Sci. Total Environ. 2014, 478, 21-24. [CrossRef] [PubMed]

283. Stroud, J.L.; Norton, G.J.; Islam, M.R.; Dasgupta, T.; White, R.P.; Price, A.H.; Meharg, A.A.; McGrath, S.P.; Zhao, F.-J. The dynamics of arsenic in four paddy fields in the Bengal delta. Environ. Pollut. 2011, 159, 947-953. [CrossRef] [PubMed]

284. Rahman, M.A.; Rahman, M.M.; Hasegawa, H. Arsenic-induced straighthead: An impending threat to sustainable rice production in south and south-east Asia! Bull. Environ. Contam. Toxicol. 2012, 88, 311-315. [CrossRef] [PubMed]

285. Panaullah, G.M.; Alam, T.; Hossain, M.B.; Loeppert, R.H.; Lauren, J.G.; Meisner, C.A.; Ahmed, Z.U.; Duxbury, J.M. Arsenic toxicity to rice (Oryza sativa L.) in Bangladesh. Plant Soil 2008, 317, 1-9. [CrossRef]

286. Ghosh, A.; Majumder, S.; Awal, M.A.; Rao, D.R. Arsenic exposure to dairy cows in Bangladesh. Arch. Environ. Contam. Toxicol. 2013, 64, 151-159. [CrossRef] [PubMed]

287. Duxbury, J.M.; Panaullah, G. Remediation of Arsenic for Agriculture Sustainability, Food Security and Health in Bangladesh; FAO Water Working Paper; Food and Agriculture Organization of the United Nations: Rome, Italy, 2007. 
288. Talukder, A.S.M.H.M.; Meisner, C.A.; Sarkar, M.A.R.; Islam, M.S. Effect of water management, tillage options and phosphorus status on arsenic uptake in rice. Ecotoxicol. Environ. Saf. 2011, 74, 834-839. [CrossRef] [PubMed]

289. Talukder, A.S.M.H.M.; Meisner, C.A.; Sarkar, M.A.R.; Islam, M.S.; Sayre, K.D.; Duxbury, J.M.; Lauren, J.G. Effect of water management, arsenic and phosphorus levels on rice in a high-arsenic soil-water system: II. Arsenic uptake. Ecotoxicol. Environ. Saf. 2012, 80, 145-151. [CrossRef] [PubMed]

290. Sarkar, S.; Basu, B.; Kundu, C.K.; Patra, P.K. Deficit irrigation: An option to mitigate arsenic load of rice grain in West Bengal, India. Agric. Ecosyst. Environ. 2012, 146, 147-152. [CrossRef]

291. Spanu, A.; Daga, L.; Orlandoni, A.M.; Sanna, G. The role of irrigation techniques in arsenic bioaccumulation in rice (Oryza sativa L.). Environ. Sci. Technol. 2012, 46, 8333-8340. [CrossRef] [PubMed]

292. Norton, G.J.; Adomako, E.E.; Deacon, C.M.; Carey, A.; Price, A.H.; Meharg, A.A. Effect of organic matter amendment, arsenic amendment and water management regime on rice grain arsenic species. Environ. Pollut. 2013, 177, 38-47. [CrossRef] [PubMed]

293. Hu, P.; Huang, J.; Ouyang, Y.; Wu, L.; Song, J.; Wang, S.; Li, Z.; Han, C.; Zhou, L.; Huang, Y.; et al. Water management affects arsenic and cadmium accumulation in different rice cultivars. Environ. Geochem. Health 2013, 35, 767-778. [CrossRef] [PubMed]

294. Hu, P.; Ouyang, Y.; Wu, L.; Shen, L.; Luo, Y.; Christie, P. Effects of water management on arsenic and cadmium speciation and accumulation in an upland rice cultivar. J. Environ. Sci. 2015, 27, 225-231. [CrossRef] [PubMed]

295. Newbigging, A.M.; Paliwoda, R.E.; Chris Le, X. Rice: Reducing arsenic content by controlling water irrigation. J. Environ. Sci. 2015, 30, 129-131. [CrossRef] [PubMed]

296. Linquist, B.A.; Anders, M.M.; Adviento-Borbe, M.A.; Chaney, R.L.; Nalley, L.L.; Da Rosa, E.F.F.; van Kessel, C. Reducing greenhouse gas emissions, water use, and grain arsenic levels in rice systems. Glob. Chang. Biol. 2015, 21, 407-417. [CrossRef] [PubMed]

297. Moreno-Jiménez, E.; Meharg, A.A.; Smolders, E.; Manzano, R.; Becerra, D.; Sánchez-Llerena, J.; Albarrán, T.; López-Piñero, A. Sprinkler irrigation of rice fields reduces grain arsenic but enhances cadmium. Sci. Total Environ. 2014, 485-486, 468-473. [CrossRef] [PubMed]

298. Yadvinder-Singh; Kukal, S.S.; Jat, M.L.; Sidhu, H.S. Improving water productivity of wheat-based cropping systems in South Asia for sustained productivity. Adv. Agron. 2014, 127, 157-258.

299. Singh, Y.; Humphreys, E.; Kukal, S.S.; Singh, B.; Kaur, A.; Thaman, S.; Prashar, A.; Yadav, S.; Timsina, J.; Dhillon, S.S.; et al. Crop performance in permanent raised bed rice-wheat cropping system in Punjab, India. Field Crops Res. 2009, 110, 1-20. [CrossRef]

300. Kukal, S.S.; Singh, Y.; Yadav, S.; Humphreys, E.; Kaur, A.; Thaman, S. Why grain yield of transplanted rice on permanent raised beds declines with time? Soil Tillage Res. 2008, 99, 261-267. [CrossRef]

301. Kreye, C.; Bouman, B.A.M.; Reversat, G.; Fernandez, L.; Vera Cruz, C.; Elazegui, F.; Faronilo, J.E.; Llorca, L. Biotic and abiotic causes of yield failure in tropical aerobic rice. Field Crops Res. 2009, 112, 97-106. [CrossRef]

302. Kreye, C.; Bouman, B.A.M.; Faronilo, J.E.; Llorca, L. Causes for soil sickness affecting early plant growth in aerobic rice. Field Crops Res. 2009, 114, 182-187. [CrossRef]

303. Kreye, C.; Bouman, B.A.M.; Castañeda, A.R.; Lampayan, R.M.; Faronilo, J.E.; Lactaoen, A.T.; Fernandez, L. Possible causes of yield failure in tropical aerobic rice. Field Crops Res. 2009, 111, 197-206. [CrossRef]

304. Ma, J.F.; Takahashi, E. Soil, Fertilizer, and Plant Silicon Research in Japan; Elsevier: Amsterdam, The Netherlands, 2002.

305. Seyfferth, A.L.; McCurdy, S.; Schaefer, M.V.; Fendorf, S. Arsenic concentrations in paddy soil and rice and health implications for major rice-growing regions of Cambodia. Environ. Sci. Technol. 2014, 48, 4699-4706. [CrossRef] [PubMed]

306. Fleck, A.T.; Mattusch, J.; Schenk, M.K. Silicon decreases the arsenic level in rice grain by limiting arsenite transport. J. Plant Nutr. Soil Sci. 2013, 176, 785-794. [CrossRef]

307. Liu, W.-J.; McGrath, S.P.; Zhao, F.-J. Silicon has opposite effects on the accumulation of inorganic and methylated arsenic species in rice. Plant Soil 2014, 376, 423-431. [CrossRef]

308. Pati, S.; Pal, B.; Badole, S.; Hazra, G.C.; Mandal, B. Effect of silicon fertilization on growth, yield, and nutrient uptake of rice. Commun. Soil Sci. Plant Anal. 2016, 47, 284-290. [CrossRef] 
309. Sanglard, L.M.V.P.; Detmann, K.C.; Martins, S.C.V.; Teixeira, R.A.; Pereira, L.F.; Sanglard, M.L.; Fernie, A.R.; Araújo, W.L.; DaMatta, F.M. The role of silicon in metabolic acclimation of rice plants challenged with arsenic. Environ. Exp. Bot. 2016, 123, 22-36. [CrossRef]

310. Sanglard, L.M.V.P.; Martins, S.C.V.; Detmann, K.C.; Silva, P.E.M.; Lavinsky, A.O.; Silva, M.M.; Detmann, E.; Araújo, W.L.; DaMatta, F.M. Silicon nutrition alleviates the negative impacts of arsenic on the photosynthetic apparatus of rice leaves: An analysis of the key limitations of photosynthesis. Physiol. Plant. 2014, 152, 355-366. [CrossRef] [PubMed]

311. Hosseini, S.Z.; Jelodar, N.B.; Bagheri, N. Study of silicon effects on plant growth and resistance to stem borer in rice. Commun. Soil Sci. Plant Anal. 2012, 43, 2744-2751. [CrossRef]

312. Haynes, R.J. A contemporary overview of silicon availability in agricultural soils. J. Plant Nutr. Soil Sci. 2014, 177, 831-844. [CrossRef]

313. Xiao, X.; Chen, B.; Zhu, L. Transformation, morphology, and dissolution of silicon and carbon in rice straw-derived biochars under different pyrolytic temperatures. Environ. Sci. Technol. 2014, 48, 3411-3419. [CrossRef] [PubMed]

314. Sistani, K.R.; Savant, N.K.; Reddy, K.C. Effect of rice hull ash silicon on rice seedling growth. J. Plant Nutr. 1997, 20, 195-201. [CrossRef]

315. Sistani, K.R.; Reddy, K.C.; Kanyika, W.; Savant, N.K. Integration of rice crop residue into sustainable rice production system. J. Plant Nutr. 1998, 21, 1855-1866. [CrossRef]

(C) 2016 by the author; licensee MDPI, Basel, Switzerland. This article is an open access article distributed under the terms and conditions of the Creative Commons Attribution (CC-BY) license (http://creativecommons.org/licenses/by/4.0/). 